\title{
A TOOL PROPOSAL TO DETECT OPERATING ANOMALIES IN THE SPANISH WHOLESALE ELECTRICITY MARKET
}

Rocío Román-Collado $^{\text {a }}{ }^{*}$; José M. Cansino ${ }^{\text {a }}{ }^{\text {, María J. Colinet }}{ }^{\mathrm{a}}$, Víctor Dugo ${ }^{\mathrm{a}}$

${ }^{*}$ Corresponding author rroman@us.es

a Universidad de Sevilla (Seville, Spain)

Department of Economic Analysis and Political Economy

Avda. Ramón y Cajal 1

41018 Seville

b Universidad Autónoma de Chile (Chile) 


\begin{abstract}
Mainly in the mass media, the operating of the wholesale electricity market in Spain is under of controversy because of the sensitivity of end consumers to the price of their electricity bill. Part of the controversy derives from possible collusive behavior from the main generation companies due they shared $55 \%$ of wholesale market. The goal of this paper is to design a tool to detect anomalies in determining electricity prices on that market. The tool claim to be used by supervisory agencies with responsibility on this market.
\end{abstract}

The tool is based on a spatial LMDI-I decomposition analysis. This methodological approach has been less developed in the literature than the temporal LMDI-I analysis. Decomposition is applied to the differences between the daily cost and monthly average cost of electricity generation. To test the smooth functioning of the tool, data was taken for a period of time in which the supervisory agency sanctioned proceedings for generation companies but also for control periods of time when no sanctions were imposed. The decomposition analysis used the price, structure and scale effects as the decomposition effects.

The proposed tool has allowed us to capture anomalous behaviours of the electricity costs in the electricity wholesale market for the same periods in which the supervisory agency in charge initiated sanctioning proceedings. These anomalies do not appear in the control periods for which the tool was tested.

KEYWORDS: electricity wholesale market, LMDI-I, spatial decomposition, pool price. 


\section{A TOOL PROPOSAL TO DETECT OPERATING ANOMALIES IN THE SPANISH WHOLESALE ELECTRICITY MARKET}

\section{Introduction.}

In Spain, the beginning of the liberalization of the electricity market took place with the transposition of the European Directive 96/92/EC (European Parliament, 1996). One aim was to reduce collusive behaviour among operating companies and reduce final prices for consumers (O'Mahoney and Denny, 2013). Afterwards the vertical integration of electricity companies was prohibited and the electricity generation and commercialization activities were carried out under free competition (Spanish Parliament, 1997). As a result, electricity companies segmented their activities (Cansino et al., 2018b).

Electric energy generation is organized in two regimes in Spain; the so-called ordinary regime (OR) and the specific reward regime of generation (previously called special regime-SR). The first includes nuclear, coal thermal, combined cycle plants, those that use petroleum or gas derivatives as their primary source, and large hydroelectric plants. The second includes wind, solar photovoltaic, solar thermal, biomass power generation, high efficiency cogeneration and waste and small hydroelectric plants (Marques et al., 2018 and Spanish Parliament, 2013b). This last regime benefit from various incentives among which it is a legal priority to pour into the grid (Ciarreta et al., 2016, 2011).

In Spain, the Spanish Division of the Iberian Market Operator (OMIE in Spanish acronym) is responsible for guaranteeing the proper functioning of the wholesale market. OMIE matches the supply and demand of electricity (Antonanzas et al., 2017, Channon and Eames, 2014, Fabra and Toro, 2005, Moutinho et al., 2014). The energy generated can be exchanged in the wholesale market (daily and intraday) or through bilateral contracts between producers and suppliers. However, the majority of electricity is exchanged in the wholesale market. In 2017, the total energy exchanged was 303.552 GWh (OMIE, 2018), sharing 80\% of the total generated electricity. Table A2 in Annex A details the agents that intervene in the market. 
Specifically, OMIE builds the aggregate supply curve by adding the bids received from the selling agents but ranked by a double criteria. First criteria determines technologies with priority to sell the generated electricity. Additionally to the nuclear, there are other technologies that enjoy this priority such as renewable energy sources (RES), cogeneration and waste, being supported by an economic system (Spanish Parliament, 2013b). The second criteria stablishes that the remainder of the electricity supply curve is built by ranking the bids received in increasing order of price (Federico et al, 2008). Likewise, the OMIE builds the demand curve based on the purchase bids received from the trading companies.

The daily market is a spot market where the bids are accepted at an increasing price until the total demand is met. The price of the latest technology supplying electricity (marginal price) establishes the price received by all the technologies that have previously entered. The price is determined by an algorithm called Euphemia developed by the company NSIDE (N-SIDE, n.d.). Once the daily wholesale market closes, the intraday market opens. In this second market the selling and trading companies adjust their offers and demands to the exact requirements for each hour so that the electric power system remains balanced (Hu et al., 2018; Scharff and Amelin, 2016; Weber, 2010). The Spanish electricity system includes a third market that is made up of sub markets named Technical restrictions markets. They operate almost at the same time than the wholesale market and is supervised by the System Operator attributed to Red Eléctrica España (REE) (Fabra and Fabra, 2009; Ortiz et al., 2016; Spanish Parliament, 2013b). In the technical restrictions markets generation purchase schemes may be modified to avoid collapses in the transmission and distribution network (Spanish Parliament, 2015, REE, 2018a).

The National Commission on Markets and Competition (CNMC in Spanish acronym) is the Spanish authority responsible for investigating potential collusive behaviour (Spanish Parliament, 2013 a). CNMC has sanctioned several firms in the period 2001-2005, 2013 and 2016-2017 (a detailed list of disciplinary proceedings is available in Annex B). One of the last proceedings is referred to the year 2013 (CNMC, 2015). The resolution of this file indicates that the generating company Iberdrola drastically cut the production capacity of its power plants to cause an increase in the wholesale market price. 
According to the resolution, the Iberdrola Generación behaviour caused an increase in the price of the daily market by around $7 € /$ MWh. This increase meant an estimated profit of 21.5 million $€$ for this company and an impact for the whole of the demand of 105 million $€$. The CNMC proposed imposing a sanction consisting of the payment of a fine about 25.000.000 €, although this amount has not been paid.

Although, Sánchez-Ortiz et al. (2016) consider that the current regulation of the Spanish electricity market cannot avoid the existence of practices contrary to free competition, the business concentration measured by the Herfindhal-Hirschmann index (HHI) shows acceptable levels. According to Costa (2016), the HHI has been reduced from 3.218 in 1997 to 1.226 in 2015. As soon as the HHI was lower than 2.000 and the market share of the largest company was under $25 \%$, the horizontal competition problems may not arise (European Parliament, 2004). The above notwithstanding, the electricity generation sector in Spain maintains a strong concentration in a small number of companies, among which Iberdrola and Endesa (part of the ENEL group) stand out (Table A3). Both companies have managed to maintain their majority share over the years which would give them market power (Fabra and Toro, 2005 and Federico et al., 2008).

The aim of this paper is to develop a tool to make easier the supervision of the wholesale electricity market contributing to a better use of resources. Only for those periods when anomalies appear efforts investigating possible collusive behaviour might be displayed. The tool is tested using data from several months of the period 2012-2014 in which the CNMC established sanctions.

The tool is based on a Logarithmic Mean Divisa Index (LMDI) decomposition analysis of the cost of electricity exchanged in the wholesale market. More specifically, the tool consists on a spatial decomposition that looks for an explanation for the difference between the daily and the monthly average cost of electricity in order to detect anomalies. Although the temporal decomposition analysis is widespread in the research literature (Ang,1995; 2004; 2005; Ang and Liu, 2001; 2007a), the spatial decomposition variant is very recent (Ang et al., 2015 and Ang et al., 2016) and allows comparisons between 
countries or regions according to their position with respect to a target or reference country or region.

Recent literature shows that the spatial decomposition has been mainly applied to the analysis of $\mathrm{CO}_{2}$ emissions although there are also case studies in which this methodology has been used to analyse the differences in energy consumption between regions. Most of these papers have been mainly focused in China. Ang et al (2015) compared 30 regions of China according to their performance in energy consumption. Wang et al (2016) analysed the driving factors of $\mathrm{SO}_{2}$ emissions for thirteen cities in Jiangsu Province (China). Liu et al (2017) assessed the emission performance of electricity generation in 30 provinces (China) and Liu et al. (2018) examine the driving forces of energy consumption and emissions of $\mathrm{CO}_{2}$ in China's cement industry. Wang et al. (2018) analysed the driving forces of aggregate carbon intensity of electricity generation in China. Chen et al. (2019) explored the driving forces of carbon intensity for China's 30 provinces and 4 regions. Liu et al. (2019) analyse driving forces of $\mathrm{CO}_{2}$ emissions in China from a sectorial as well as a regional perspective. Alternatively, there are other cases of study such as Ang and Goh (2016) that analyse the factors that contribute to the differences in the intensity of $\mathrm{CO}_{2}$ emissions for the countries that belong to the Association of Southeast Asian Nations (ASEAN) and Román and Morales (2018) that explore the driving forces behind the growth of $\mathrm{CO}_{2}$ emissions for the 20 Latin American.

The novelty of this paper is to apply this methodological approach to the cost of electricity in the Spanish wholesale electricity market. Additionally, the steps carried out with this methodology will allow us to provide a tool for detecting operating anomalies in the Spanish wholesale electricity market. As far as we are aware, this type of tool has not previously been used to supervise the operation of any wholesale electricity market, so this paper contributes to fill this gap in the literature.

The paper is structured as follows. After the introduction the section 2 shows the main characteristics of the wholesale electricity market in Spain listing sanctions imposed in the analysed period. Section 3 describes the methodology developed and database. The main result are presented and discussed in section 4. Finally, section 5 summarizes the main conclusions. 


\section{Methodology and data.}

The developed tool to detect anomalies in the operation of the wholesale electricity market in Spain is based on Index Decomposition Analysis (IDA); more specifically Logarithmic Mean Divide Index (LMDI) approach in its spatial version (SP-IDA). This approach allows us to detect anomalies in electricity cost values by analysing the decomposition of the differences between the daily and the monthly average electricity cost.

In this paper, the spatial LMDI analysis is going to be carry out in its additive formulation. The analysis includes the eight technologies that pour into the Spanish wholesale market (conventional hydraulics, pure pumping hydro, nuclear, domestic coal, import coal, combined cycle, RES’ regime and import).

To do so, firstly, the daily cost of electricity for each of the $j=1 \ldots 8$ technologies considered at the disaggregated level is broken down as follows:

$C_{i j}=\frac{C_{i j}}{E_{i j}} \cdot \frac{E_{i j}}{E_{i}} \cdot E_{i}=P_{i j} \cdot S_{i j} \cdot A_{i}$

Where $C_{i}$ is the daily cost of electricity, $C_{i j}$ is the cost of electricity for the day $i$ for technology $j\left(C_{i j}=\operatorname{Ppool}_{i} * E_{i j}\right)$, Ppool $_{i}$ is the pool price in day $i, E_{i j}$ is the daily electricity generated by technology $j(j=1 \ldots 8), E_{i}$ is the total daily electricity generated. From (1) the daily cost of electricity is broken down into three factors: pool price $\left(P_{i}\right)$ structure $\left(S_{i}\right)$ and scale $\left(A_{i}\right)$. The cost electricity for each day and technologies is calculated as a sum of the hour/day energy cost.

Secondly, the spatial LMDI decomposition analysis requires defining the monthly representative cost of electricity. This is what equation (2) does:

$\bar{C}_{j}=\frac{\bar{C}_{j}}{\bar{E}_{j}} \cdot \frac{\bar{E}_{j}}{\bar{E}} \cdot \bar{E}=\bar{P}_{j} \cdot \bar{S}_{j} \cdot \bar{A}$ 
where $\bar{C}$ is the monthly average of the electricity cost $(\bar{C}=\bar{P}$ pool $* \bar{E})$; $\bar{P}$ pool is the weighted monthly average of the pool price, that is $\bar{P}$ pool $=\frac{\sum P \text { pool }_{i} \cdot E_{i}}{\bar{E}}$, being $\bar{C}_{j}$ the monthly average of electricity cost of each technology $\mathrm{j}, \bar{E}_{\mathrm{J}}$ is the monthly average of the electricity generated by technology $\mathrm{j}(j=1 \ldots 8)$, by last $\bar{E}$ is the monthly average of the total electricity generated.

From (1) and (2) it is possible to decompose the difference between the total costs for each day of the month $(i=1 \ldots 31)$ and the monthly average cost as detailed (3)

$\Delta C=C_{i j}-\bar{C}_{j}=\Delta P+\Delta S+\Delta A$

In Eq. (3) $\Delta P$ is the price effect. It measures what part of the difference between the daily cost and the average monthly cost of an electricity generation technology is due to the price of the electricity generation. High values for $\Delta P$ (in absolute terms) must correspond to peak day (high demand and / or mix of generation composed of the most expensive technologies) or valley (reduced demand and / or generation mix composed of lower cost technologies). The structure effect $\Delta S$ measures what part of the difference between the daily cost and the average monthly cost of an electricity generation technology is due to the relative weight of that technology over the total of electricity generation. High values for $\Delta S$ (in absolute terms) must correspond to a high share of the most expensive or less expensive technologies. Finally, the scale effect $\Delta A$ measures what part of the difference between the daily cost and the average monthly cost of an electricity generation technology is due to the total demand for electricity. High values of $\Delta A$ (in absolute terms) should correspond to peak o valley days (high or low demand respectively).

Each of these effects are mathematically defined below:

$$
\Delta P=w_{i j} \cdot \ln \left(\frac{P_{i j}}{\overline{P_{j}}}\right)
$$




$$
\begin{aligned}
& \Delta S=w_{i j} \cdot \ln \left(\frac{S_{i j}}{\overline{S_{j}}}\right) \\
& \Delta A=w_{i j} \cdot \ln \left(\frac{A_{i}}{\bar{A}}\right)
\end{aligned}
$$

Applying the Mean Value Theorem, the weight factor $w_{i j}$ used for the calculation of the different effects is defined in (7).

$$
w_{i j}=L\left(C_{i j}, \bar{C}_{j}\right)=\frac{C_{i j}-\overline{C_{j}}}{\ln C_{i j}-\ln \bar{C}_{j}}
$$

\subsection{Data.}

The hourly prices ( $€ / \mathrm{MWh}$ ) data of the daily electricity market for the 2012-2014 period have been accessed from the historical files of the OMIE (OMIE, 2014). The data of the electricity generation (MWh) for each hour come from the historical files registered in the website of the OMIE (OMIE, 2017).

The period analysed has been the month of December for the years 2012, 2013 and 2014. The month of December of 2013 has been chosen because is the period sanctioned by the CNMC. Additionally, the months of December of 2012 and 2014 has been selected to be compared with the previous results.

\section{Results.}

The first step implementing the tool is to analyse the differences between the daily and monthly average electricity cost in December 2013 (when sanctions were imposed). The data for December 2013 is then compared with December 2012 and 2014 (used as control periods because no sanctions were imposed).

The technologies chosen in the analysis are the Conventional Hydraulic or great hydropower (> $20 \mathrm{MW}$ ), the combined cycle energy plants (CCP) and those included in 
the so called special regime. We use 'special regime' because it is the most extended term despite is not currently used at legal level. Most important technologies in the special regime are those based on RES. The reasons why they have been selected have been the following. The sanctions posed by the CNMC pointed to the Conventional Hydraulic energy plants. Additionally, the RES are also of interest as far as the electricity provided by them and the CCP should be decoupled. The electricity produced by RES (mainly wind and photovoltaic) is intermittent as they depend on climatic and environmental factors such as the sun hours and the wind speed. These technologies enjoy of priority to pure into the grid so their sell is guaranteed. Against to what happens with the RES plants, the CCP act as the close mechanism of the system to guarantee it is balanced. When electricity poured from RES is coupled with electricity poured from CCP an anomaly appears. This anomaly could derives from collusive behaviour of generation companies if the own plants operating with different technologies.

Due to the high cost of the electricity produced by the CCP, this technology is the last one to go in and therefore, has to compensate the lack of electricity produced by the RES when there are adverse climatic factors. In general, it is expected that when the electricity produced by RES is high, the electricity produced by the CCP should be low. Otherwise, the situation should be analysed as a possible anomaly that can cause an increase in the total cost of electricity.

As recommends the research literature (Ang et al., 2016), the results are going to be displayed in Figures 1, 2, 3 and 4. Figures 1 and 2 allow the reader to identify easily those periods when the daily electricity costs are higher or lower than the monthly average. If there are large differences during a month, this means that the daily electricity costs changes are important.

The behaviour of the electricity costs for the three technologies in December 2013 is different from December 2012 and 2013. When the tool is implemented, it is observed that the behaviour of electricity costs in December 2013 shows anomalies. During the first part of the month (days 1-18) and almost for all technologies, the daily cost of electricity are above the monthly average cost, except the day 15th (Figure 1). 
Figure 1. Differences in electricity cost generation (€). Year 2013.

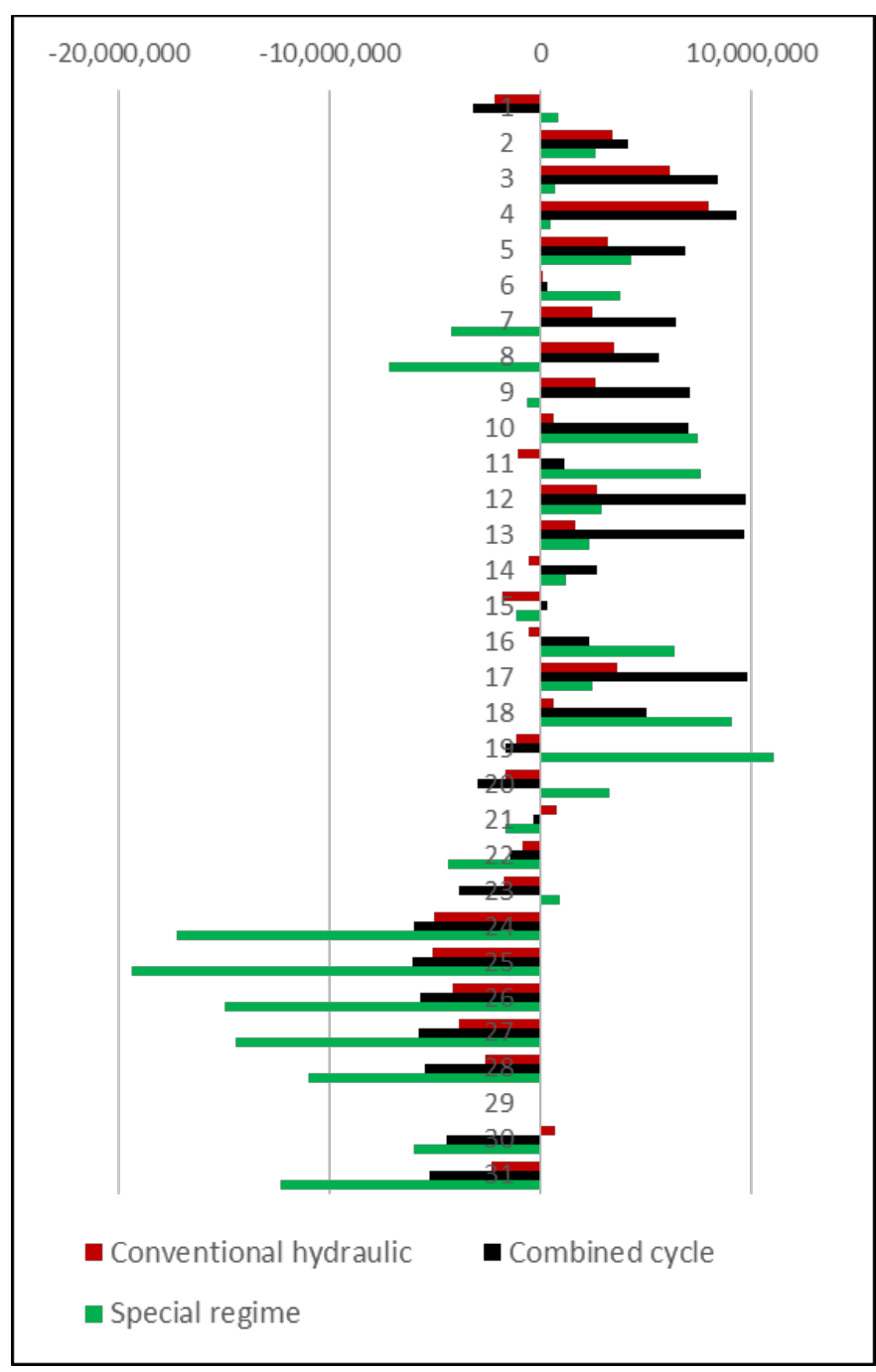

Source: Own elaboration

On the contrary, since December 20th 2013, a change in the electricity cost trend is shown for mostly all technologies. The change is relevant for the Conventional Hydraulic, CCP and renewable energies. For these technologies, the daily electricity costs are lower than the average being particularly important for the renewable energies.

In the months of December 2012 and 2014, a similar behaviour was observed for the last part of the month (starting on the 20th), the daily electricity costs for almost all technologies are lower than the average (Figure 2). The only exception is recorded on December 22 and 23, 2014, in which the negative difference of the daily electricity costs 
of the renewable energies are compensated by the positive difference of daily electricity costs due to Conventional Hydraulic and CCP.

Figure 2. Differences in electricity cost generation. Year 2012 and 2014 (€).

a) December 2012

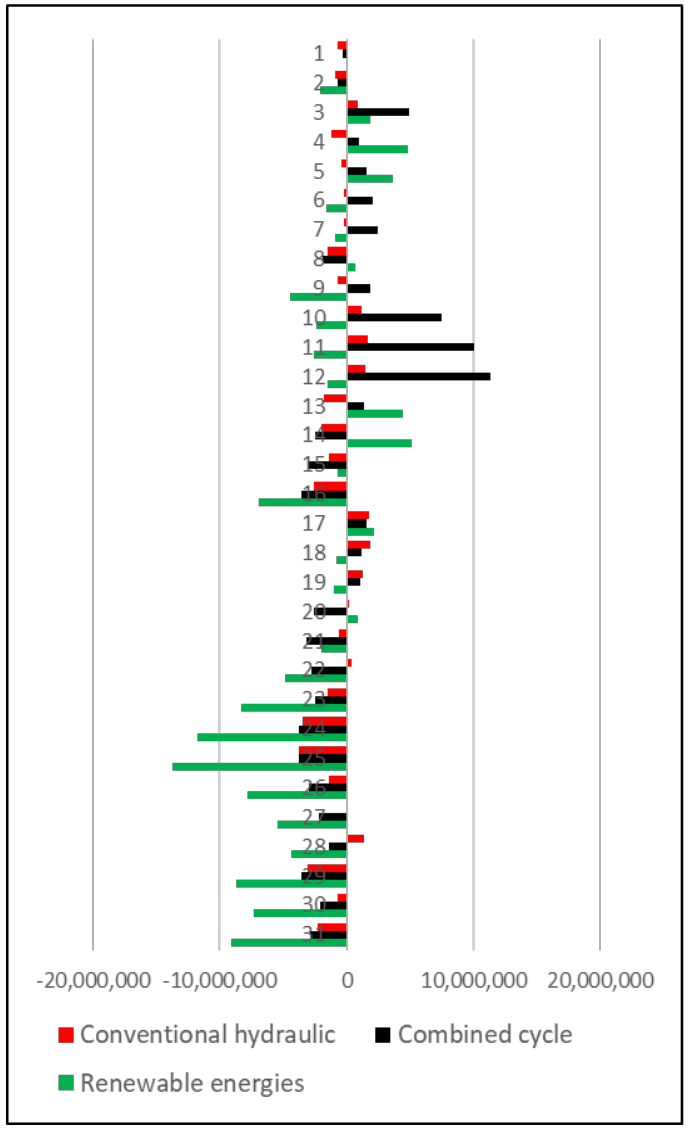

Source: Own elaboration c) December 2014

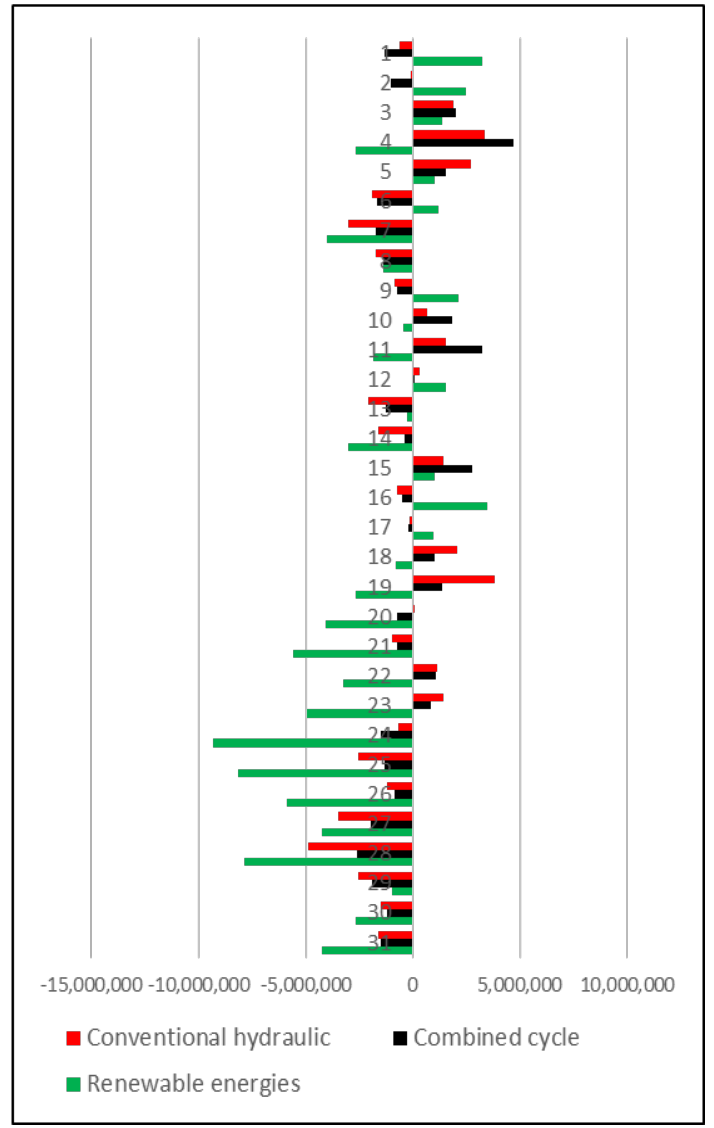

However, when the first part of the months of December is analysed, for the years 2012 and 2014 the tool advises that the days in which the daily electricity cost is above or below the monthly average appear discontinuously and without a clear pattern. This behaviour is different from the one observed in 2013 -period sanctioned by the CNMC- since the daily electricity costs were mostly recorded above the monthly average.

The second step in the tool implementation consists on the analysis of the decomposition effects that are behind the differences between the daily and monthly average electricity costs of all technologies. The spatial decomposition would allow CNMC to disaggregate, 
for each technology, the difference between the daily and the monthly average electricity costs into three effects: price, structural and scale.

Figure 3. Price, structure and scale effect (2013) (€)

a) Renewable energies

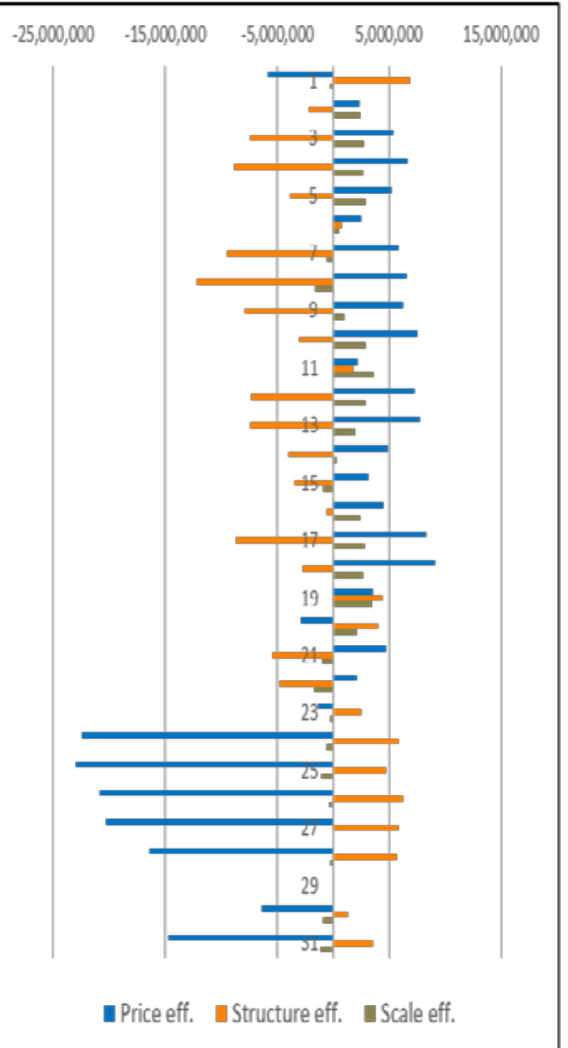

b) Conventional Hydraulic

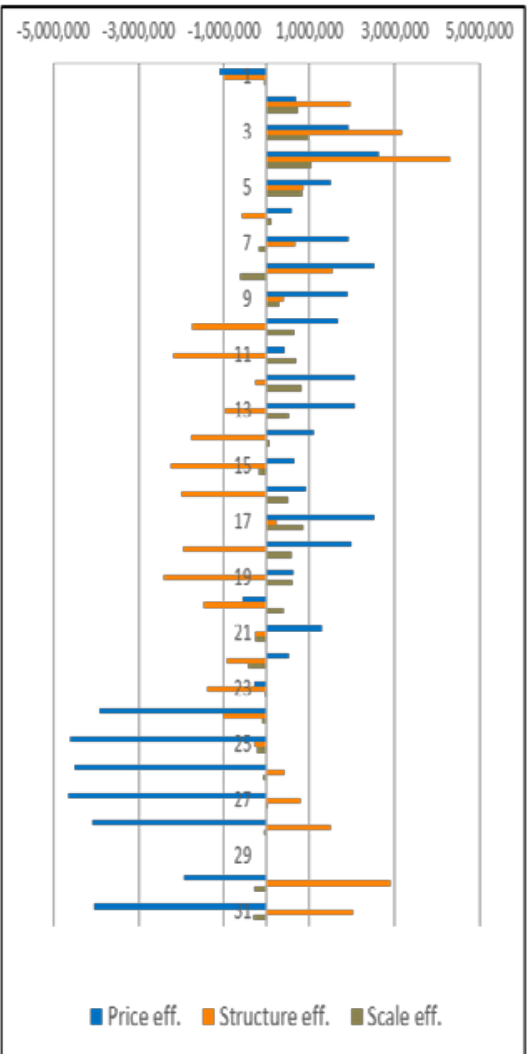

c) Combined Cycle

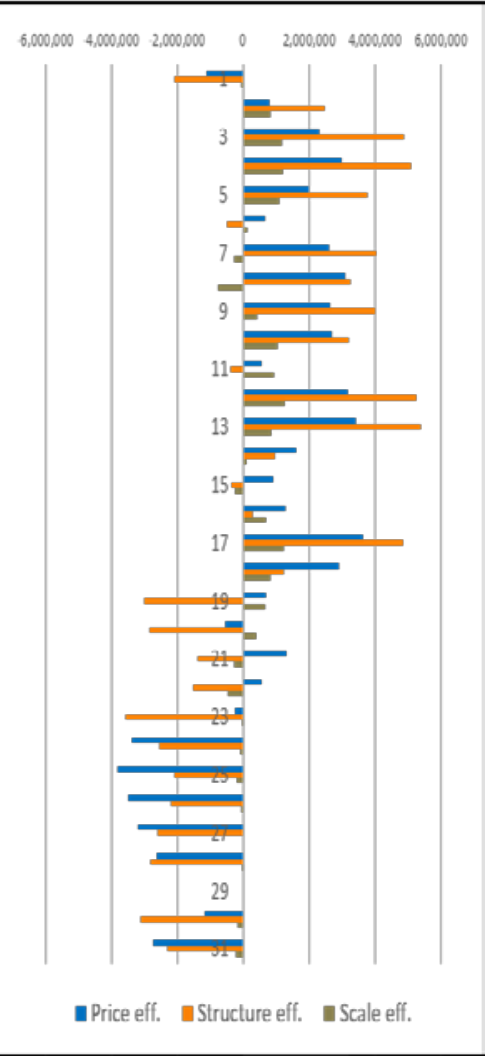

Source: Own elaboration

The Price effect shows the influence that the pool Price has on the difference between the daily and monthly average electricity costs of all technologies. When the Price effect is positive, this means that the daily pool price is higher than the monthly average pool price, being a driver effect of the electricity costs. During the first part of December 2013 (between the $2^{\text {nd }}$ and the $18^{\text {th }}$ ), the Price effect is positive acting as a driver for all technologies (Figure 3). From December $22^{\text {nd }}$ 2013, the Price effect of the technologies analysed is negative and acts as an inhibitor, that is, the daily electricity costs are lower than the monthly average, being highlighted the renewable energies. 
In order to detect if the behaviour of the price effect is due to an anomaly, it is compared with the price effect in December 2012 and December 2014. The results shows that for the first part of these latest months (between the 2nd and 18th), the price effect acts sometimes as a driver and others as an inhibitor without following a regular path (Figures 4 and 5). Therefore, during the first part of the month, the price effect in 2013 is different from the results provided by the same decomposition implemented in December 2012 and 2014. However, for the rest part of the month, in December 2012 and December 2014, the price effect acts as an inhibitor, that is, reduces the differences between the daily and monthly average electricity costs. Similarly to what happens in December 2013, the tool advises that the price effect is more important in the case of the renewable energies.

Therefore, the analysis of the price effect shows that during the first part of December 2013 (between the $2^{\text {nd }}$ and the $18^{\text {th }}$ ), had a behaviour different from other years. Concretely, the price effect acts as a driver and therefore, is increasing the difference between the daily and the monthly average electricity costs of the three technologies analysed (see Figure 2 and 3). What draws our attention is the large period of the month that the daily price of each technology is higher than the monthly average price, being compensated during the $22^{\text {nd }}$ and $31^{\text {st }}$, a shorter period with larger reductions of the price effects for the three technologies but concretely, for the renewable energies.

Figure 4. Price, structure and scale effect (2012) (€) 
a) Renewable energies

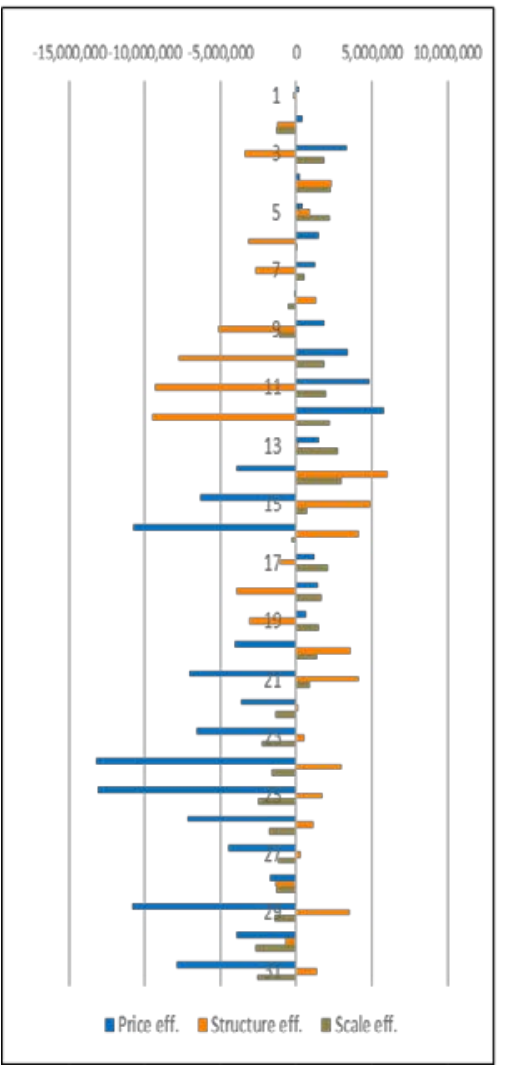

b) Conventional Hydraulic

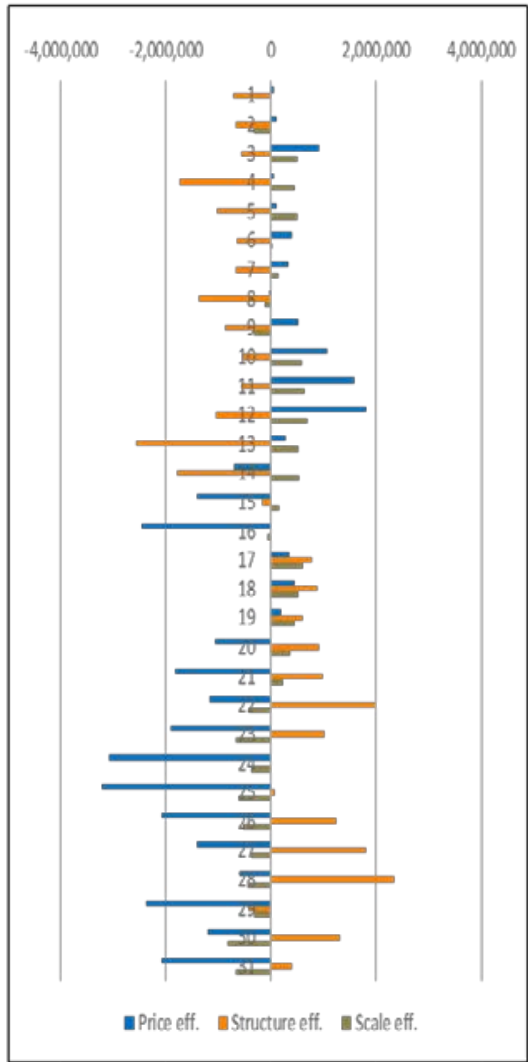

c) Combined Cycle

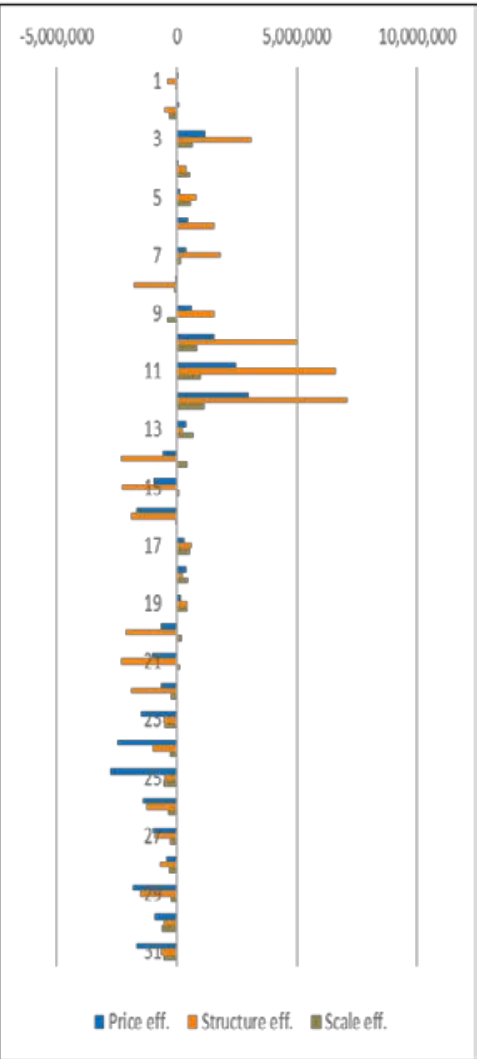

Source: Own elaboration

The scale effect is also measured by the tool and shows the influence that the electricity demand has on the difference between the daily and the monthly average electricity costs. When the Scale effect is positive, the daily electricity demand is higher than the monthly average, acting as a driver effect of the electricity costs. In December 2013, between the $2^{\text {nd }}$ and $18^{\text {th }}$, the scale effect follows a similar path than the price effect for all technologies although there are some days that show negative values such as the $7^{\text {th }}, 8^{\text {th }}$ and $15^{\text {th }}$. Since December $22^{\text {nd }} 2013$, the scale effect is an inhibitor of the electricity costs for the three technologies showing a reduction in the electricity demand for those days (Figure 3). In comparison with the changes shown by the price effects, the variations of the electricity costs due to the scale effect are much lower.

When the scale effect for 2013 is compared with the decomposition results for December 2012 and December 2014, we can conclude that the behaviour is quite similar during 
these three years. The two periods can be distinguished and the variations produced are not significant.

Finally, the third effect that measure the tool -the structure effect- shows the influence that the relative weight of each technology has on the differences between the daily and monthly average costs of electricity. When the structure effect is positive for one technology this means that the daily weight of this technology on total generation is higher than the monthly average, being a driver of the electricity costs.

In December 2013, between the $2^{\text {nd }}$ and $22^{\text {nd }}$, the structure effect does not follow the same path for the three technologies. In the case of the renewable energies, with some exceptions, the structure effect is an inhibitor of the electricity costs differences, but in the case of CCP, also with some exceptions, is a driver. In the case of the Conventional Hydraulic, the structure effect is a driver between the $2^{\text {nd }}$ and the $9^{\text {th }}$ and is an inhibitor between the $10^{\text {th }}$ and the 22th. What we can see is that when the renewable energies decrease its weight, the CCP increases, but the Conventional Hydraulic has only increased weight during the $2^{\text {nd }}$ and $9^{\text {th }}$. However, during the rest of the month, the structure effect is a driver of the renewable energies and Conventional Hydraulic and is an inhibitor for the CCP.

Figure 5. Price, structure and scale effects (2014) (€) 

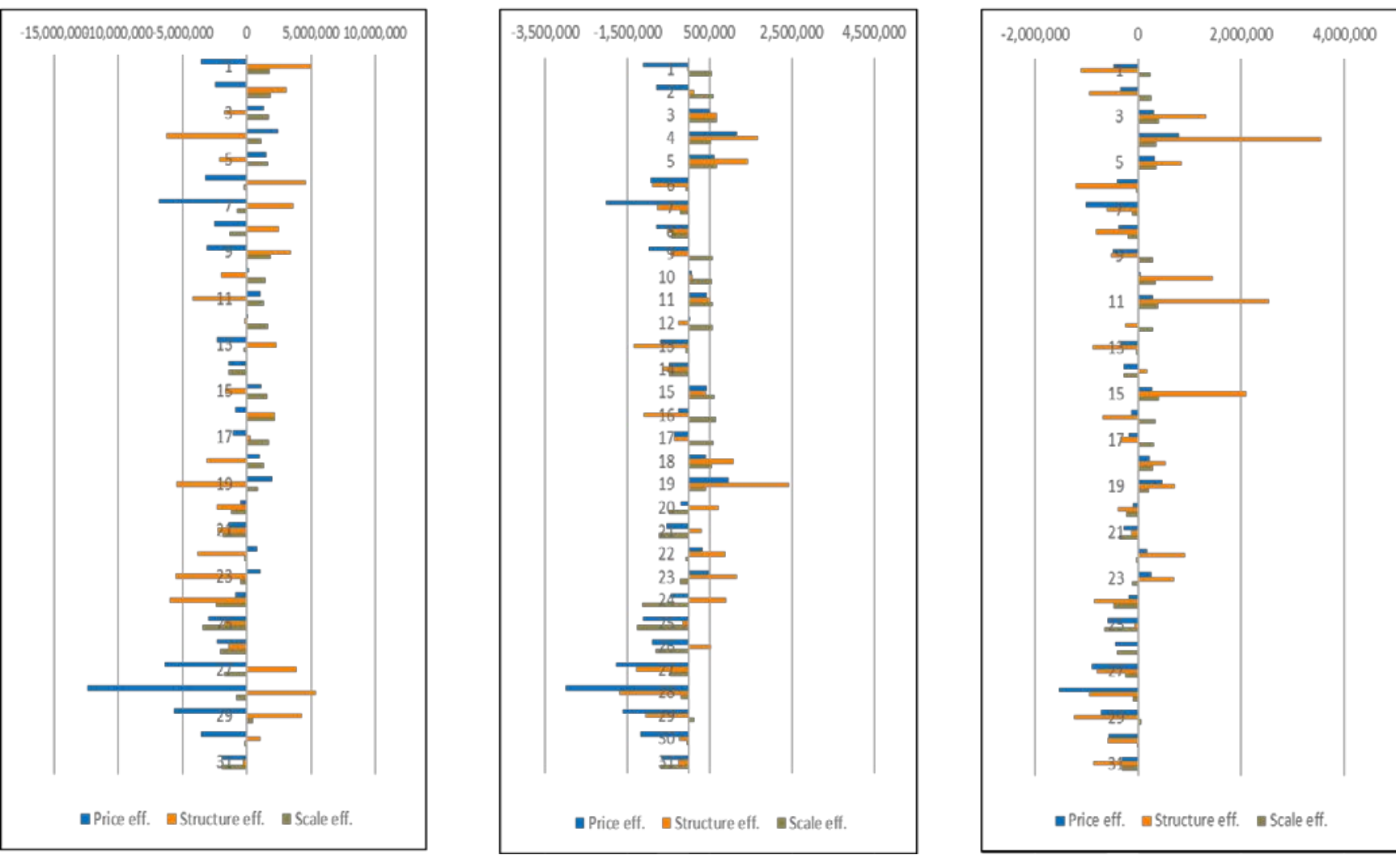

Source: Own elaboration

In order to test the importance of this effect, the results of the structure effect in December 2013 are compared with those in 2012 and 2014. The analysis for 2012 shows that during the first subperiod of December 2012 (between the $2^{\text {nd }}$ and $20^{\text {th }}$ ) the structure effect of the Conventional Hydraulic is an inhibitor and for the CCP is a driver. The contrary behaviour occurs in the second part of December 2012. In the case of the renewable energies, the structure effect does not follow a regular path.

In December 2014, the structure effect for the CCP and Conventional Hydraulic is sometimes a driver and others an inhibitor effect (Figure 5). However, it should be highlighted that the renewable energies always follow a different pattern than these technologies, that is, when the structure effect is a driver for the CCP and Conventional Hydraulic, is an inhibitor for the renewable energies. This trend is always similar during December 2014. Therefore, when the renewable energies increase weight in total generation, the other two technologies are not required to enter in. However, if renewable 
energies reduce weight (negative structure effect), the other two increase to meet the electricity demand.

\section{Discussion.}

The results of the decomposition effects provided by the tool allow CNMC to access to useful information to better supervise the right functioning of the electricity system. A discussion of these results should highlight some policy implications.

The sanctioned behaviour was identified during a period when the market show high prices due to the high demand. The CNMC investigated this period during more than three weeks (between November 30 and December 23, 2013). The infringing was associated with the reduction of hydroelectric power generation in the Duero, Sil and Tajo rivers`stations. What the CNMC highlights was that the hydraulic resources, capable of generating electricity at lower prices, were not properly used to meet the demand. This decision forced to put into production the CCP owned by the same company but whose offers were made at a higher price.

The operating of the wholesale market allows us conclude that for periods when the scale effect is positive and the structure effect of the renewable energies is negative, the Conventional Hydraulic might shows a positive structure effect. If the share of the Conventional Hydraulic does not increase in the wholesale market, then the CCP might increase as this is an enclosure technology used to balance the system (showing a positive structure effect). Probably, in these cases, the CCP and the other technologies, would also show a positive price effect. However, it is also expected that the Conventional Hydraulic should increase their share on total electricity generation when the demand increases (positive scale effect) and the Renewable energies decrease their weight (negative structure effect).

In December 2013, between the $10^{\text {th }}$ and $18^{\text {th }}$, when special regime showed positive values for the scale effect but negative for the structure effect, the Conventional Hydraulic showed negative values for its structure effect. So instead of increasing Conventional Hydraulic, this technology follows the similar trend than the Special Regime despite of 
there was enough quantity of water disposable in hydropower plants to be used. This is a central issue upon which CNMC’s sanctions were built.

In the case of December 2012, this situation occurs between the $9^{\text {th }}$ and $12^{\text {th }}$, when the scale effects were positive and the renewable energies show a structure effect negative, then the Conventional Hydraulic decreases its relative weight on total electricity generation (structure effect negative). In this case, the anomaly lasts few days and the price effects increase during those days very moderately. During the rest of the month, the behaviour of the effects for all technologies do not show anomalies.

Another anomaly during December 2013 is that the price effect is always positive between the $2^{\text {nd }}$ and the 22th, showing that the daily price of electricity cost during those days were always higher the monthly average. In fact, the positive differences are quite important. This behaviour does not appear in December 2012 and 2014. The price effect is alternative positive and negative during the month.

Although results identify anomalies in the daily wholesale electricity market in December 2013, doubts arise as to whether the possible reduction in hydroelectric plants was caused by the reserve of available water or not. Then, electricity generation by hydroelectric power plants are analysed in detail. Table 2 (GWh) and Table 3 (percentage values) show the total available energy (Month of December) by the hydroelectric plants according to the geographical area. It is shown that the available peninsular energy (GWh) in 2013 and in 2014 is higher than the average of the last 5 years as well as the last 10 years. Focusing on the Miño-Sil, Duero and Tajo power plants (stations investigated for possible manipulation in the electricity generation), it is perceived that during the year 2013 the amounts of available energy were similar or even higher than the average of the previous years. During December 2013, the energy available in these plants was much higher than the previous year.

Therefore, the analysis of the capacity of the hydroelectric power plants during December 2013 shows that the lack of available energy was not the reason why these plants cut production. Then, a possible collusive behaviour could explain the decisions of the generation companies of reducing hydropower generation. These companies might force 
CCP to generate electricity in order to balance the system but with higher costs, getting more profit as they are the owners of both technologies.

The proceeding of the CNMC concluded that the sanctioned generating company reduced the supply of hydroelectric power drastically in the month of December 2013, although in the previous month, the electricity generation was much higher. Therefore, analysing this data, it cannot be concluded that the generation company has cut down electricity generation because of a lower capacity. This sanction goes in line with results from the tool December 2013, between the 10th and $18^{\text {th. }}$

Regarding the control periods when no sanctions were imposed, results were as was expected. In December 2012, when the scale effects are positive and the share of Renewable energies were reduced, the Conventional Hydraulic increased its relative weight on total electricity generation (positive structure effect). Additionally, when Price and scale effects were positive, structure effect for CCP acts as a driver. Together with this, structure effect for special regime use to act as expected inhibiting higher costs. No anomalies appear for the other control period, December 2014. 
Table 2. Total available energy (GWh) in December.

\begin{tabular}{|c|c|c|c|c|c|c|}
\hline \multirow{2}{*}{$\begin{array}{c}\text { Geographic } \\
\text { area }\end{array}$} & \multirow{2}{*}{$\begin{array}{c}\text { Total } \\
\text { Capacity }\end{array}$} & \multicolumn{4}{|c|}{ Years } & \multirow{2}{*}{$\begin{array}{l}\text { Average } \\
10 \text { Years }\end{array}$} \\
\hline & & 2014 & 2013 & 2012 & 5 Years & \\
\hline $\begin{array}{l}\text { Cantábrico } \\
\text { Occidental }\end{array}$ & 183 & 82 & 144 & 150 & 152 & 146 \\
\hline Miño - Sil & 2,635 & 1,802 & 1,452 & 1,108 & 1,489 & 1,440 \\
\hline Galicia Costa & 236 & 156 & 217 & 190 & 191 & 182 \\
\hline Duero & 5,064 & 4,200 & 3,163 & 1,487 & 2,720 & 2,901 \\
\hline Tajo & 1595 & 977 & 1089 & 930 & 1069 & 1198 \\
\hline Guadalquivir & 21 & 14 & 13 & 19 & 31 & 33 \\
\hline $\begin{array}{l}\text { Vertiente } \\
\text { Atlántica }\end{array}$ & 9,734 & 7,231 & 6077 & 3885 & 5652 & 5899 \\
\hline Segura & 4 & 3 & 3 & 4 & 3 & 3 \\
\hline Júcar & 34 & 21 & 42 & 38 & 41 & 41 \\
\hline Ebro & 1,624 & 1,129 & 1,327 & 1,146 & 1,157 & 1,120 \\
\hline $\begin{array}{c}\text { Vertiente } \\
\text { Mediterránea }\end{array}$ & 1,662 & 1,153 & 1,372 & 1,188 & 1,202 & 1,164 \\
\hline $\begin{array}{c}\text { Total } \\
\text { peninsular }\end{array}$ & 22,792 & 16,768 & 14,898 & 10,145 & 13,708 & 14,127 \\
\hline
\end{tabular}

Source: Ministry of Ecological Transition (2019).

Table 3. Total available energy (\%) in December

\begin{tabular}{|c|c|c|c|c|c|}
\hline \multirow{2}{*}{ Geographic area } & \multicolumn{3}{|c|}{ Capacity \% } \\
\cline { 2 - 5 } & \multicolumn{3}{|c|}{ Years } & \multicolumn{2}{c|}{ Average } \\
\cline { 2 - 5 } & 2014 & 2013 & 2012 & 5 Years & 10 Years \\
\hline Cantábrico Occidental & $45 \%$ & $79 \%$ & $82 \%$ & $83 \%$ & $80 \%$ \\
\hline Miño - Sil & $68 \%$ & $55 \%$ & $42 \%$ & $57 \%$ & $55 \%$ \\
\hline Galicia Costa & $66 \%$ & $92 \%$ & $81 \%$ & $81 \%$ & $77 \%$ \\
\hline Duero & $83 \%$ & $62 \%$ & $29 \%$ & $54 \%$ & $57 \%$ \\
\hline Tajo & $61 \%$ & $68 \%$ & $58 \%$ & $67 \%$ & $75 \%$ \\
\hline Guadalquivir & $69 \%$ & $61 \%$ & $91 \%$ & $147 \%$ & $155 \%$ \\
\hline Vertiente Atlántica & $74 \%$ & $62 \%$ & $40 \%$ & $58 \%$ & $61 \%$ \\
\hline Segura & $75 \%$ & $85 \%$ & $90 \%$ & $85 \%$ & $85 \%$ \\
\hline Júcar & $62 \%$ & $122 \%$ & $113 \%$ & $122 \%$ & $119 \%$ \\
\hline Ebro & $70 \%$ & $82 \%$ & $71 \%$ & $71 \%$ & $69 \%$ \\
\hline Vertiente Mediterránea & $69 \%$ & $83 \%$ & $71 \%$ & $72 \%$ & $70 \%$ \\
\hline Total peninsular & & & & & \\
\hline
\end{tabular}

Source: Ministry of Ecological Transition (2019). 


\section{Conclusions and policy implications.}

This paper tests a feasible tool to be used for the Spanish authority supervising the right functioning of the wholesale electricity market. The tool was tested for three periods of time. One with imposed sanctions derived from collusive behaviour in generation companies (December, 2013) and two others without sanctions (December, 2012 and December, 2014). The tool detects certain anomalies in Conventional Hydraulic plants that are in line with the arguments of the imposed sanctions. So the tool is revealed as a useful one.

Firstly, the price effect highlights those periods when the difference between the daily and monthly average pool price is higher. These differences might be occasional or as it happens in December 2013, might last for many days and show large variations. In this later case, the positive differences extend during the first part of December 2013, between the $2^{\text {nd }}$ and the $18^{\text {th }}$.

Secondly, the scale effect and the structure effect should be analysed together. A positive scale effect for the technologies, is expected to be followed by a positive structure effect of renewable energies. However, these technologies are conditioned by climatic factors, so if they were not able to increase electricity (structure effect negative for this technology), the Conventional Hydraulic is expected to increase unless this technology had some restrictions such us lower water dam. In case, the Conventional Hydraulic shows a negative structure effect without being generation restrictions, an anomaly is found. In this case, the CCP would increase (structure effect positive) and of course, the price effect will show positive values.

Despite data used are from the Spanish case, the tool can be used for any other market of a different country with a similar electricity system. That is what happens in part of the European electricity market.

It might be highlighted that this tool should not be the only instrument to detect anomalies in the Spanish wholesale electricity market. In fact, the tool do no capture intentionality 
behind decisions taken nor by the technics in charge managing the power plants nor by their owner. To detect this intentionality and if this is motivate for a collusive behaviour correspond to personal working for the CNMC. The tool just point out periods with anomalies where the focus might be put. In this sense, the tool contributes to a better allocation of human, capital and financial resources.

Future research might be to test this tool in the Spanish restrictions market of electricity.

\section{Acknowledgements.}

First three authors are grateful for the financial support received from the Chair of Energy and Environmental Economics sponsored by Red Eléctrica España (REE) at the University of Seville. First two authors acknowledge the support from Universidad Autónoma de Chile (Chile). Authors are also grateful to the Spanish Ministerio de Ciencia, Innovación y Universidades for the financial support received from the research project (RTI2018-096725-B-I00).

\section{References.}

Ang, B. W., Goh, T., 2016. Carbon intensity of electricity in ASEAN: Drivers, performance and outlook. Energy Policy, 98, 170-179.

Ang, B. W., Liu, F. L., 2001. A new energy decomposition method: perfect in decomposition and consistent in aggregation. Energy, 26(6), 537-548.

Ang, B. W., Liu, F.L., 2007 . Negative-value problems of the logarithmic mean Divisia index decomposition approach, Energy Policy, 35(1) 739-742.

Ang, B. W., Xu, X. Y., Su, B., 2015. Multi-country comparisons of energy performance: the index decomposition analysis approach. Energy Economics, 47, 68-76.

Ang, B.W., 1995. Decomposition methodology in industrial energy demand analysis. Energy 20, 1081-1095.

Ang, B.W., 2004. Decomposition analysis for policymaking in energy: which is the preferred method?. Energy Policy, 32(9), 1131-1139.

Ang, B.W., 2005. The LMDI approach to decomposition analysis: a practical guide. Energy Policy 33, 867-871.

Ang, B.W., Su, B., Wang, H., 2016. A spatial-temporal decomposition approach to performance assessment in energy and emissions. Energy Economics, 60, 112-121.

Antonanzas, J., Pozo-Vázquez, D., Fernandez-Jimenez, L.A., Martinez-de-Pison, F.J., 2017. The value of day-ahead forecasting for photovoltaics in the Spanish electricity market. Solar Energy, 158, 140-146. 
Barlow, M. T., 2002. A diffusion model for electricity prices. Mathematical finance, 12(4), 287-298.

Borovkova, S., Schmeck, M. D., 2017 . Electricity price modeling with stochastic time change. Energy Economics, 63, 51-65.

Cansino, J.M., Román, R., Colinet, M.J., 2018b. Two smart energy management models for the Spanish electricity system. Utilities Policy 50, 60-72.

Catalão, J. P. D. S., Pousinho, H. M. I., \& Mendes, V. M. F., 2011. Short-term electricity prices forecasting in a competitive market by a hybrid intelligent approach. Energy Conversion and Management, 52(2), 1061-1065.

Channon, S.W., Eames, P.C., 2014. The cost of balancing a parabolic trough concentrated solar power plant in the Spanish electricity spot markets. Solar Energy, 110, 83-95.

Chen, C., Zhao, T., Yuan, R., \& Kong, Y., 2019. A spatial-temporal decomposition analysis of China's carbon intensity from the economic perspective. Journal of Cleaner Production, 215, 557-569.

Ciarreta, A., Gutiérrez-Hita, C., Nasirov, S., 2011. Renewable energy sources in the Spanish electricity market: Instruments and effects. Renewable and Sustainable Energy Reviews, 15, 2510-2519.

Ciarreta, A., Nasirov, S., Silva, C., 2016. The development of market power in the Spanish power generation sector: Perspectives after market liberalization. Energy Policy 96, 700-710.

Comisión Nacional de los Mercados y la Competencia (CNMC), 2015. SNC/DE/0046/14: IBERDROLA GENERACIÓN SAU. Barcelona: Sala de supervisión regulatoria. Available in https://www.cnmc.es/expedientes/sncde004614 .

Comisión Nacional de los Mercados y la Competencia (CNMC), 2016. Informe de supervisión del mercado peninsular de producción de energía eléctrica (2015). Available in https://www.cnmc.es/ambitos-de-actuacion/energia/mercado-electrico

Conejo, A. J., Plazas, M. A., Espinola, R., \& Molina, A. B., 2005. Day-ahead electricity price forecasting using the wavelet transform and ARIMA models. IEEE transactions on power systems, 20(2), 1035-1042.

Contreras, J., Espinola, R., Nogales, F. J., \& Conejo, A. J., 2003. ARIMA models to predict next-day electricity prices. IEEE transactions on power systems, 18(3), 10141020.

Costa Campi, M. T., 2016. Evolución del sector eléctrico español (19752015). Información Comercial Española, ICE: Revista de economía, 889, 139-156.

Díaz Mendoza, A. C., Larrea Basterra, M., Álvarez Pelegry, E., \& Mosácula Atienta, C. (2015). De la liberalización (Ley 54/1997) a la reforma (Ley 24/2013) del sector eléctrico español. Cuadernos Orkestra, 10, 1-103.

electricity price projections using Bayesian emulation of a generation investment model. Sustainable Energy, Grids and Networks, 13, 42-55.

Fabra, N., Fabra, J., 2009. Competencia y poder de mercado en los mercados eléctricos. Cuadernos Económicos de ICE, 79.

Fabra, N., Toro, J., 2005. Price wars and collusion in the Spanish electricity market. International Journal of Industrial Organization, 23, 155-181.

Federico, G., Vives, X., Fabra, N., 2008. Competition and regulation in the Spanish gas and electricity markets. Reports of the Public-Private Sector Research Center, ISBN: 84-86851-73-4.

García-Martos, C., Rodriguez, J., \& Sanchez, M. J., 2007. Mixed models for short-run forecasting of electricity prices: application for the Spanish market. IEEE Transactions on Power Systems, 22(2), 544-552. 
Haldrup, N., \& Nielsen, M. Ø., 2006. A regime switching long memory model for electricity prices. Journal of econometrics, 135(1-2), 349-376.

Hu, J., Harmsen, R., Crijns-Graus, W., Worrell, E., van den Broek, M., 2018. Identifying barriers to large-scale integration of variable renewable electricity into the electricity market: A literature review of market design. Renewable and Sustainable Energy Reviews, 81, 2181-2195.

Islyaev, S., Date, P., 2015. Electricity futures price models: Calibration and forecasting. European Journal of Operational Research, 247(1), 144-154.

Kanamura, T., \& Ōhashi, K., 2007. A structural model for electricity prices with spikes: Measurement of spike risk and optimal policies for hydropower plant operation. Energy economics, 29(5), 1010-1032.

Li, H., Zhao, Y., Qiao, X., Liu, Y., Cao, Y., Li, Y., Weng, J., 2017. Identifying the driving forces of national and regional CO2 emissions in China: Based on temporal and spatial decomposition analysis models. Energy Economics, 68, 522-538.

Liu, J., Zhang, S., Wagner, F., 2018. Exploring the driving forces of energy consumption and environmental pollution in China's cement industry at the provincial level. Journal of Cleaner Production, 184, 274-285.

Liu, L. C., Fan, Y., Wu, G., Wei, Y. M. 2007. Using LMDI method to analyze the change of China's industrial $\mathrm{CO}_{2}$ emissions from final fuel use: An empirical analysis. Energy Policy, 35(11), 5892-5900.

Liu, N., Ma, Z., Kang, J., 2017. A regional analysis of carbon intensities of electricity generation in China. Energy Economics, 67, 268-277.

Marques, A.C., Fuinhas, J.A., Neves, S.A., 2018. Ordinary and Special Regimes of electricity generation in Spain: How they interact with economic activity. Renewable and Sustainable Energy Reviews, 81, 1226-1240.

Ministry of Ecological Transition, 2019. Boletín Hidrológico. Available in http://eportal.mapama.gob.es/BoleHWeb/ . Last access june 2019.

Moreira, R., Bessa, R., \& Gama, J., 2016. Probabilistic forecasting of day-ahead electricity prices for the Iberian electricity market. In 2016 13th International Conference on the European Energy Market (EEM) (pp. 1-5). IEEE.

Moutinho, V., Moreira, A.C., Mota, J., 2014. Do regulatory mechanisms promote competition and mitigate market power? Evidence from Spanish electricity market. Energy Policy 68, 403-412.

N-SIDE, n.d. https://www.n-side.com/pcr-euphemia-algorithm-european-powerexchanges-price-coupling-electricity-market/ . Accesed, september, 2018.

O’Mahoney, A., Denny, E., 2013. Electricity prices and generator behaviour in gross pool electricity markets. Energy Policy 63, 628-637.

Operador del Mercado Eléctrico de la Energía-Polo Español (OMIE), 2014. Precios hora del mercado diario. Available in http://www.omie.es/files/flash/ResultadosMercado.swf . Last access , may 2018).

Operador del Mercado Eléctrico de la Energía-Polo Español (OMIE), 2017. Generación de energia por tecnología . Available in http://www.omie.es/aplicaciones/datosftp/datosftp.jsp?path=/contratacion stota/ . Last access, may 2018).

Operador del Mercado Eléctrico de la Energía-Polo Español (OMIE), 2018. Resultados de Mercado. Available in http://www.omie.es/files/flash/ResultadosMercado.swf (Last access , september 2018).

Ortiz, M., Ukar, O., Azevedo, F., Múgica, A., 2016. Price forecasting and validation in the Spanish electricity market using forecasts as input data. International Journal of 
Electrical Power \& Energy Systems, 77, 123-127.

Palmer, K., Paul, A., Keyes, A., 2018. Changing Baselines, Shifting Margins: How Predicted Impacts of Pricing Carbon in the Electricity Sector Have Evolved over Time. Energy Economics. In press.

Parlamento español, 1997. Jefatura de Estado, Ley 54/1997, de 27 de noviembre, del Sector Eléctrico. Publicado en el BOE n. 285. pp. 35097-35126.

Parlamento español, 2013a. Jefatura de Estado, Ley 3/2013, de 4 de junio, de creación de la Comisión Nacional de los Mercados y la Competencia. Publicado en el BOE n. 134. pp. 42191-42243.

Parlamento español, 2013b. Jefatura de Estado, Ley 24/2013, de 26 de diciembre, del Sector Eléctrico. Publicado en el BOE n. 310. pp 105198-105294.

Parlamento español, 2015. Jefatura de Estado, Resolución 18 de diciembre de 2015, adaptación Real Decreto 413/2014, de 6 de junio. Publicado en el BOE n. 303. pp 119723-119944.

Parlamento europeo, 1996. Directiva 96/92/CE sobre las normas comunes para el mercado interior de la electricidad. Publicado en el Diario Oficial n. L027 de 30/01/1997 pp. 0020-0029.

Parlamento europeo, 2004. Directrices sobre la evaluación de las concentraciones horizontales con arreglo al Reglamento del Consejo sobre el control de las concentraciones entre empresas (2004/C 31/03). Publicado en el Diario Oficial n. C 31 de 05/02/2004 pp. 5-18.

Pousinho, H. M. I., Mendes, V. M. F., \& Catalão, J. P. D. S., 2012. Short-term electricity prices forecasting in a competitive market by a hybrid PSO-ANFIS approach. International Journal of Electrical Power \& Energy Systems, 39(1), 29-35.

Rafiei, M., Niknam, T., \& Khooban, M. H., 2017. Probabilistic electricity price forecasting by improved clonal selection algorithm and wavelet preprocessing. Neural Computing and Applications, 28(12), 3889-3901.

Red Eléctrica Española (REE), 2017. Precio hora en el mercado diario. Available in https://www.esios.ree.es/es . Último acceso, mayo 2018.

Red Eléctrica Española (REE), 2018a. Operación del sistema eléctrico. Available in http://www.ree.es/es/actividades/operacion-del-sistema-electrico . Last access, june 2018.

Red Eléctrica Española (REE), 2019. Estadísticas. Available in https://www.ree.es/es/estadisticas-del-sistema-electrico-espanol/seriesestadisticas/series-estadisticas-nacionales . Last access , May 2019.

Redl, C., Haas, R., Huber, C., Böhm, B., 2009. Price formation in electricity forward markets and the relevance of systematic forecast errors. Energy Economics, 31(3), 356-364.

Román-Collado, R., Morales, V., 2018. Towards a sustainable growth in Latin America: A multiregional spatial decomposition analysis of the driving forces behind CO2 emissions changes. Energy Policy, 115, 273-280.

Sánchez-Ortiz, J., García-Valderrama, T., Rodríguez-Cornejo, V., 2016. Towards a balanced scorecard in regulated companies: A study of the Spanish electricity sector. The Electricity Journal, 29, 36-43.

Scharff, R., Amelin, M., 2016. Trading behaviour on the continuous intraday market Elbas. Energy Policy, 88, 544-557.

Shrivastava, N. A., \& Panigrahi, B. K., 2014. A hybrid wavelet-ELM based short term price forecasting for electricity markets. International Journal of Electrical Power \& Energy Systems, 55, 41-50

Wang, J., He, S., Qiu, Y., Liu, N., Li, Y., Dong, Z., 2018. Investigating driving forces of 
aggregate carbon intensity of electricity generation in China. Energy Policy, 113, 249-257.

Wang, Y., Wang, Q., Hang, Y., 2016. Driving factors of SO2 emissions in 13 cities, Jiangsu, China. Energy Procedia, 88, 182-186.

Weber, C., 2010. Adequate intraday market design to enable the integration of wind energy into the European power systems. Energy Policy, 38, 3155-3163.

Weigt, H., von Hirschhausen, C., 2008 . Price formation and market power in the German wholesale electricity market in 2006. Energy policy, 36(11), 4227-4234.

Weron, R., 2007. Modeling and forecasting electricity loads and prices: A statistical approach (Vol. 403). John Wiley \& Sons.N. Haldrup, M.Ø. Nielsen.

Weron, R., 2014. Electricity price forecasting: A review of the state-of-the-art with a look into the future. International journal of forecasting, 30(4), 1030-1081.

Wilson, A. L., Dent, C. J., Goldstein, M., 2018. Quantifying uncertainty in wholesale electricity price projections using Bayesian emulation of a generation investment model. Sustainable Energy, Grids and Networks, 13, 42-55.

Zhang, J., Tan, Z., \& Yang, S., 2012. Day-ahead electricity price forecasting by a new hybrid method. Computers \& Industrial Engineering, 63(3), 695-701.

Ziel, F., Steinert, R., Husmann, S., 2015a. Efficient modeling and forecasting of electricity spot prices. Energy Economics, 47, 98-111.

Ziel, F., Steinert, R., Husmann, S., 2015b . Forecasting day ahead electricity spot prices: The impact of the EXAA to other European electricity markets. Energy Economics, $51,430-444$. 
Annex A.

Table A1. Electric Power Installed by technologies (MW). National Level.

\begin{tabular}{|l|c|c|c|c|}
\hline & $\mathbf{2 0 1 2}$ & $\mathbf{2 0 1 4}$ & $\mathbf{2 0 1 6}$ & $\mathbf{2 0 1 8}$ \\
\hline Hydraulics & 19,804 & 19,898 & 20,362 & 20,378 \\
\hline Nuclear & 7,853 & 7,866 & 7,573 & 7,117 \\
\hline Carbon & 11,758 & 11,482 & 10,004 & 10,030 \\
\hline Fuel / gas & 3,429 & 3,309 & 2,490 & 2,490 \\
\hline Combined cycle & 27,194 & 27,199 & 26,670 & 26,284 \\
\hline Hydrowind & & 12 & 12 & 11 \\
\hline Wind & 22,722 & 23,002 & 23,050 & 23,507 \\
\hline Solar photovoltaic & 4,538 & 4,672 & 4,686 & 4,714 \\
\hline Solar thermal & 2,000 & 2,300 & 2,304 & 2,304 \\
\hline Other renewable (1) & 957 & 1,018 & 858 & 865 \\
\hline Cogeneration & 7,361 & 7,196 & 5,979 & 5,741 \\
\hline Waste & & & 659 & 652 \\
\hline Total & 107,615 & 107,954 & 104,647 & 104,094 \\
\hline
\end{tabular}

(1) Includes biogas, biomass, marine hydraulics and geothermal.

Source: REE (2019).

Table A2. Agents involved in the Spanish wholesale electricity market.

\begin{tabular}{|l|l|}
\hline Agents* & Type \\
\hline \multirow{4}{*}{ Sellers } & Producers \\
\cline { 2 - 2 } & Traders \\
\cline { 2 - 2 } & Importer \\
\cline { 2 - 2 } & Other intermediary \\
\hline \multirow{2}{*}{ Purchasers } & Marketers \\
\cline { 2 - 2 } & Reference's marketers \\
\cline { 2 - 2 } & Direct consumer \\
\hline
\end{tabular}

* All of them qualified by the system.

Source: Own elaboration 
Table A3. Electricity generation business quotas in the Spanish wholesale market in the daily and intraday program $(\%)$.

\begin{tabular}{|l|l|l|l|l|l|l|l|l|l|l|l|l|l|}
\hline Year & Endesa & Iberdrola & $\begin{array}{l}\text { U. } \\
\text { Fenosa* }\end{array}$ & $\begin{array}{l}\text { G. } \\
\text { Natural }\end{array}$ & EDP & Viesgo & AXPO & Acciona & WTM** & $\begin{array}{l}\text { Energya } \\
\text { VM }\end{array}$ & NEXUS & Others & HHI \\
\hline 2008 & $27 \%$ & $24 \%$ & $12 \%$ & $6 \%$ & $5 \%$ & $1 \%$ & $4 \%$ & $3 \%$ & $1 \%$ & $1 \%$ & $1 \%$ & $14 \%$ & 1600 \\
\hline 2009 & $21 \%$ & $25 \%$ & $7 \%$ & $7 \%$ & $5 \%$ & $4 \%$ & $6 \%$ & $3 \%$ & $2 \%$ & $2 \%$ & $1 \%$ & $16 \%$ & 1309 \\
\hline 2010 & $19 \%$ & $25 \%$ & $0 \%$ & $13 \%$ & $5 \%$ & $3 \%$ & $7 \%$ & $5 \%$ & $2 \%$ & $2 \%$ & $2 \%$ & $16 \%$ & 1397 \\
\hline 2011 & $22 \%$ & $23 \%$ & $0 \%$ & $13 \%$ & $5 \%$ & $3 \%$ & $7 \%$ & $5 \%$ & $2 \%$ & $3 \%$ & $2 \%$ & $15 \%$ & 1374 \\
\hline 2012 & $22 \%$ & $20 \%$ & $0 \%$ & $13 \%$ & $5 \%$ & $3 \%$ & $8 \%$ & $5 \%$ & $2 \%$ & $3 \%$ & $2 \%$ & $16 \%$ & 1281 \\
\hline 2013 & $22 \%$ & $21 \%$ & $0 \%$ & $12 \%$ & $6 \%$ & $2 \%$ & $8 \%$ & $6 \%$ & $3 \%$ & $3 \%$ & $2 \%$ & $16 \%$ & 1286 \\
\hline 2014 & $22 \%$ & $23 \%$ & $0 \%$ & $11 \%$ & $5 \%$ & $3 \%$ & $8 \%$ & $5 \%$ & $3 \%$ & $2 \%$ & $2 \%$ & $15 \%$ & 1338 \\
\hline 2015 & $22 \%$ & $21 \%$ & $0 \%$ & $11 \%$ & $6 \%$ & $3 \%$ & $7 \%$ & $5 \%$ & $3 \%$ & $2 \%$ & $2 \%$ & $17 \%$ & 1226 \\
\hline
\end{tabular}

* In 2009, the acquisition of Unión Fenosa by Natural Gas took place, constituting Gas NaturalFenosa.

** Wind to Market.

Source: CNMC (2016) 
Annex B.

Files and press release to large electricity generation companies for infractions of the antitrust regulations.

- In the resolution of the sanctioning file 552/02 Electric Companies, several electricity generation companies are officially initiated (ENDESA, IBERDROLA, UNIÓN FENOSA, HIDROCANTÁBRICO) for behaviours prohibited by law 16/1989, July 17 , defence of competition. In the disciplinary proceedings $\left(n^{\circ} 2388 / 01\right)$ these companies are declared authors and responsible for an infringement of article 6 of the Antitrust Law consisting of abusing the dominant position in the electricity supply markets, in a context of technical restrictions on days 19, 20 and November 21, 2001,in four geographical supply zones. The abuse consisted, from a dominant position they obtained advantages that would have been unaffordable under competitive conditions. These companies presented offers at prices substantially higher than their disclosed variable costs, compared with those offered in similar situations, so that they would be excluded from the matching process of the daily market, and knowing that their offer would be in any case, necessary to meet the demand in the subsequent electricity supply market to resolve technical constraints. It is intimated to refrain from carrying out prohibited practices and an economic sanction is imposed.

- In the resolution of the disciplinary proceedings 601/05, Iberdrola (Exp. 2560/04, of the Service for the Defense of Competition) dated 8-3-07, it is initiated ex officio by the General Directorate of Competition against Iberdrola Generación, S.A. Unipersonal for having incurred an abuse of a dominant position prohibited by article 6.1.a) of the Law on the Defense of Competition, by offering to the daily energy market prices not for their matching in said market, but to generate in a situation of technical restrictions, in whose situation was the only possible bidder, behaviour that took place, in a continuous manner. For the Castellón plant between December 18, 2002 and May 27, 2003 and between October 23 and December 31, 2003, and during the year 2003 in the Escombreras 4 and Escombreras 5 plants. He is again advised to refrain from carrying out such practices and a fine of 38.710 .349 euros is imposed.

- In the resolution of the disciplinary proceedings 602/05 Viesgo Generación, ENEL VIESGO GENERACIÓN, S.L. is declared responsible for an infringement of Article 6 of the LDC, consisting of abusing its dominant position in the electricity market in a situation of technical restrictions in the South-Central and South areas, on February 20 and 21, 9 and April 23 and October 27 and 28, 2002, January 17-19, February 15-17 and May 17-18, 2003, offering to the daily market at prices higher than its disclosed variable costs, in order not to marry in the daily market and knowing that it would be called to technical restrictions, and paid at its daily offer price, because its energy was necessary to satisfy the demand of the area, being the only one available from it. It is intimated to refrain in the successive of carrying out sanctioned practices, prohibited by the LDC and a fine of 2,500,000 euros is imposed.

- In the resolution of the disciplinary proceedings 624/07 Iberdrola, IBERDROLA GENERACIÓN S.A. is declared guilty of abuse of a dominant position prohibited by Article 6 of the Law on the Defense of Competition, by offering to the daily energy market prices not being cashed in said market, but to generate in situation of technical 
restrictions, in whose situation was the only possible bidder, behaviour that took place, continuously, for the central Castellón 3 between June 18 and December 31, 2004 and days 3 , 4, 6, 7, 9, 15, 16, 22, 23, 26, 27, 29 and 30 of January 2005 and 5, 6, 12, 13, 14, 15, 16, 17, 18, 19, 20, 26 and 27 of February of 2005. It is intimated to refrain from such practices and a fine of 15.400 .000 euros is imposed.

- In the resolution of the disciplinary proceedings 625/07 Gas Natural, GAS NATURAL ELECTRICDAD SDG, S.A. is declared, guilty of abuse of a dominant position prohibited by Article 6 of the Law on the Defense of Competition, on days 7, 8, 9, 12, 13, 14, 15, 16, 19, 20, 21, 22, 23, 26, 28, 29 and 30 of January; 2, 3, 4, 5, 6, 9, 10, 11, 12, 13, 16, 17, 18, 19, 20, 23, 24, 25, 26 and 27 February; 1, 2, 3, 4, 5, 8, 9, 10, 11, 12, 15, 16, 17, 18, 23, 24, 25, 26, 29, 30 and 31 March; 1, 2, 6, 14 and 15 of April, and 2, 3, 4, 7, 8, 9, 10, 11, 14, 15, 16, 17 and 18 of June of 2004, in which San Roque 1 plant, located in the South Zone and enjoying a position of dominance in the market of technical restrictions in the area on those days, offered the daily energy market prices much higher than the prices that were forming in the market, and this not to marry in the daily market be called to produce in technical restrictions, and charge for the energy produced for technical constraints the higher price of its offer to the newspaper. It is intimated to abstain from such practices and a fine of 1.500 .000 euros is imposed.

- In the resolution of the file S/0104/08 Eléctricas initiated by the National Competition Commission against IBERDROLA, S.A., ENDESA, S.A., E.ON ESPAÑAS.L., GAS NATURAL SDG, S.A., HIDROELÉCTRICA DEL CANTÁBRICO, S.A., C.T. ACECA, NUEVA GENERADORA DEL SUR, S.A., la central térmica GICC de ELCOGAS, GDF SUEZ ENERGÍA ESPAÑA, S.A.U., IBERDROLA DISTRIBUCIÓN ELÉCTRICA S.A., y COMPAÑÍA ESPAÑOLA DE PETROLEOS S.A., for supposed restrictive practices of competition contemplated in Law 15/2007, of July 3, on Defense of Competition. It was stated that there was no evidence in the file of the violation of Articles 1 and 2 of the LDC.

- In the resolution of file SNC/DE/0046/14 indicates that the generating company IBERDROLA S.A drastically cut the production capacity of its power plants to cause an increase in the wholesale market price. The sanctioned behaviour was carried out at a time when the market was at high prices due to the high demand. The investigated period lasted for more than three weeks (between November 30 and December 23, 2013). The infringing was associated with the reduction of hydroelectric power generation in the Duero, Sil and Tajo rivers' stations. As a consequence, the hydraulic resources capable of generating electricity at reduced prices were not properly used to meet the demand. This forced to put into production the combined cycle plants owned by the same company whose offers were made at a higher price. According to the resolution, the Iberdrola Generación behaviour caused an increase in the price of the daily market by around 7 euros / MWh. This increase meant an estimated profit of 21.5 million euros for this company and an impact for the whole of the demand of 105 million euros. The CNMC proposed imposing a sanction consisting of the payment of a fine about 25.000.000 euros 
- $\quad$ Press release: On December 10, 2017, the CNMC (National Commission of Markets and Competition) has filed proceedings against Gas Natural Fenosa Generación and Endesa Generación for allegedly serious infringement of Article 65.34 of Law 24/2013 of the Electric Sector between October 2016 and January 2017. The Energy Directorate has observed signs of possible alteration of the so-called pool generation dispatch to obtain higher revenues in restricted markets (adjustments that are made due to security of supply). They would have made an abnormally high offer for these plants to participate in the market of restrictions and thus obtain higher revenues. In this way, they would have prevented their programming for several days - despite the fact that the generalized context of high prices should have led to the opposite situation - with full knowledge of the company's high probability that the plants would end up being programmed due to technical restrictions (for reasons of security of supply). 
Annex C.

Table C1. Decomposition effects. Year 2013.

\begin{tabular}{|c|c|c|c|c|c|c|c|c|c|}
\hline \multirow[t]{2}{*}{ Day } & \multicolumn{3}{|c|}{ Price effect } & \multicolumn{3}{|c|}{ Structure effect } & \multicolumn{3}{|c|}{ Scale effect } \\
\hline & $\begin{array}{l}\text { Conventional } \\
\text { hydraulic }\end{array}$ & $\begin{array}{l}\text { Combined } \\
\text { cycle }\end{array}$ & $\begin{array}{l}\text { Renewable } \\
\text { energies }\end{array}$ & $\begin{array}{l}\text { Convention } \\
\text { al hydraulic }\end{array}$ & $\begin{array}{l}\text { Combined } \\
\text { cycle }\end{array}$ & $\begin{array}{l}\text { Renewable } \\
\text { energies }\end{array}$ & $\begin{array}{l}\text { Conventional } \\
\text { hydraulic }\end{array}$ & $\begin{array}{l}\text { Combined } \\
\text { cycle }\end{array}$ & $\begin{array}{l}\text { Renewable } \\
\text { energies }\end{array}$ \\
\hline 1 & $-1,646,728$ & $-1,678,941$ & $-8,604,374$ & $-1,060,208$ & $-2,200,569$ & 7,231,779 & $-50,307$ & $-51,291$ & $-262,860$ \\
\hline 2 & $-35,980$ & $-41,377$ & $-120,594$ & $2,068,360$ & $2,616,309$ & $-2,319,314$ & 773,404 & 889,419 & $2,592,213$ \\
\hline 3 & $1,128,203$ & $1,357,848$ & $3,147,333$ & $3,327,468$ & $5,119,012$ & $-7,837,589$ & $1,035,599$ & $1,246,395$ & $2,888,997$ \\
\hline 4 & $1,781,099$ & $2,037,724$ & $4,549,490$ & $4,499,567$ & $5,330,028$ & $-9,331,514$ & $1,100,724$ & $1,259,318$ & $2,811,596$ \\
\hline 5 & 811,128 & $1,072,848$ & 2,845,379 & 907,884 & $3,968,102$ & $-4,084,553$ & 875,204 & $1,157,599$ & $3,070,154$ \\
\hline 6 & 4,660 & 5,352 & 20,251 & $-613,363$ & $-521,377$ & 778,275 & 123,160 & 141,438 & 535,197 \\
\hline 7 & $1,295,655$ & $1,765,883$ & $3,953,452$ & 711,589 & $4,240,852$ & $-10,038,813$ & $-201,287$ & $-274,340$ & $-614,191$ \\
\hline 8 & $1,871,607$ & $2,304,785$ & $4,923,018$ & $1,635,021$ & $3,430,063$ & $-12,851,840$ & $-645,675$ & $-795,114$ & $-1,698,364$ \\
\hline 9 & $1,268,103$ & $1,753,654$ & $4,165,394$ & 427,933 & 4,199,739 & $-8,316,107$ & 318,381 & 440,287 & $1,045,800$ \\
\hline 10 & $1,137,410$ & $1,812,726$ & $5,071,481$ & $-1,836,942$ & $3,363,069$ & $-3,196,953$ & 692,975 & $1,104,416$ & $3,089,834$ \\
\hline 11 & $-103,677$ & $-141,933$ & $-541,644$ & $-2,300,078$ & $-388,325$ & $1,857,431$ & 730,233 & 999,685 & $3,815,000$ \\
\hline 12 & $1,438,835$ & $2,200,725$ & $5,088,191$ & $-273,327$ & $5,515,177$ & $-7,718,073$ & 868,269 & $1,328,034$ & $3,070,484$ \\
\hline 13 & $1,496,818$ & $2,449,446$ & $5,609,731$ & $-1,034,271$ & $5,639,656$ & $-7,803,192$ & 552,954 & 904,874 & $2,072,347$ \\
\hline 14 & 605,378 & 868,098 & $2,666,559$ & $-1,869,108$ & $1,010,643$ & $-4,229,341$ & 69,292 & 99,364 & 305,218 \\
\hline 15 & 189,691 & 265,438 & 904,418 & $-2,389,357$ & $-369,087$ & $-3,626,246$ & $-191,805$ & $-268,396$ & $-914,497$ \\
\hline 16 & 400,916 & 562,361 & $1,950,008$ & $-2,111,671$ & 323,435 & $-600,949$ & 523,988 & 734,993 & $2,548,617$ \\
\hline 17 & $1,864,232$ & 2,687,209 & $6,150,842$ & 254,554 & $5,092,673$ & $-9,125,926$ & 905,081 & $1,304,635$ & 2,986,221 \\
\hline 18 & $1,453,208$ & $2,116,869$ & $6,648,705$ & $-2,051,994$ & $1,305,144$ & $-2,868,402$ & 610,808 & 889,756 & $2,794,564$ \\
\hline 19 & 123,549 & 135,833 & 694,830 & $-2,544,470$ & $-3,162,030$ & $4,631,948$ & 645,627 & 709,824 & $3,630,969$ \\
\hline 20 & $-1,094,518$ & $-1,082,029$ & $-5,631,197$ & $-1,568,020$ & $-3,018,171$ & $4,275,096$ & 426,347 & 421,482 & $2,193,517$ \\
\hline 21 & 714,466 & 740,337 & $2,620,531$ & $-284,314$ & $-1,450,140$ & $-5,723,312$ & $-283,188$ & $-293,443$ & $-1,038,684$ \\
\hline 22 & 1,527 & 1,653 & 6,036 & $-976,603$ & $-1,611,722$ & $-5,065,136$ & $-452,205$ & $-489,679$ & $-1,787,712$ \\
\hline 23 & $-801,507$ & $-701,457$ & $-3,972,750$ & $-1,478,938$ & $-3,803,912$ & $2,677,738$ & $-48,469$ & $-42,419$ & $-240,241$ \\
\hline 24 & $-4,428,672$ & $-3,848,706$ & $-25,274,876$ & $-1,096,494$ & $-2,761,902$ & $6,254,802$ & $-113,134$ & $-98,318$ & $-645,665$ \\
\hline 25 & $-5,170,647$ & $-4,310,570$ & $-25,721,462$ & $-309,279$ & $-2,267,795$ & $5,087,325$ & $-235,498$ & $-196,325$ & $-1,171,487$ \\
\hline 26 & $-5,137,689$ & $-3,989,505$ & $-23,635,875$ & 441,502 & $-2,365,471$ & $6,623,042$ & $-88,033$ & $-68,359$ & $-404,996$ \\
\hline 27 & $-5,312,973$ & $-3,686,366$ & $-23,078,366$ & 854,171 & $-2,779,587$ & $6,184,528$ & 64 & 44 & 276 \\
\hline 28 & $-4,773,525$ & $-3,097,945$ & $-19,191,272$ & $1,592,698$ & $-3,020,707$ & $6,000,038$ & $-65,198$ & $-42,313$ & $-262,120$ \\
\hline 29 & & & & & Jnavailable & & & & \\
\hline 30 & $-2,675,885$ & $-1,648,268$ & $-8,832,778$ & $3,053,542$ & $-3,299,968$ & $1,381,154$ & $-295,253$ & $-181,867$ & $-974,595$ \\
\hline 31 & $-4,750,222$ & $-3,238,135$ & $-17,318,430$ & $2,141,661$ & $-2,455,128$ & $3,768,436$ & $-335,673$ & $-228,822$ & $-1,223,801$ \\
\hline
\end{tabular}


Table C2. Decomposition effects. Year 2012.

\begin{tabular}{|c|c|c|c|c|c|c|c|c|c|}
\hline \multirow[t]{2}{*}{ Day } & \multicolumn{3}{|c|}{ Price effect } & \multicolumn{3}{|c|}{ Structure effect } & \multicolumn{3}{|c|}{ Scale effect } \\
\hline & $\begin{array}{l}\text { Conventional } \\
\text { hydraulic }\end{array}$ & $\begin{array}{l}\text { Combined } \\
\text { cycle }\end{array}$ & $\begin{array}{l}\text { Renewable } \\
\text { energies }\end{array}$ & $\begin{array}{l}\text { Conventiona } \\
\text { l hydraulic }\end{array}$ & $\begin{array}{l}\text { Combined } \\
\text { cycle }\end{array}$ & $\begin{array}{l}\text { Renewable } \\
\text { energies }\end{array}$ & $\begin{array}{l}\text { Conventional } \\
\text { hydraulic }\end{array}$ & $\begin{array}{l}\text { Combined } \\
\text { cycle }\end{array}$ & $\begin{array}{c}\text { Renewable } \\
\text { energies }\end{array}$ \\
\hline 1 & 47,092 & 46,487 & 194,669 & $-716,184$ & $-382,356$ & $-166,189$ & $-3,293$ & $-3,250$ & $-13,611$ \\
\hline 2 & 111,348 & 107,642 & 443,459 & $-660,328$ & $-502,276$ & $-1,263,630$ & $-329,830$ & $-318,851$ & $-1,313,592$ \\
\hline 3 & 907,854 & $1,178,308$ & $3,359,770$ & $-571,362$ & $3,095,913$ & $-3,382,585$ & 498,110 & 646,500 & $1,843,398$ \\
\hline 4 & 47,025 & 57,402 & 235,701 & $-1,729,359$ & 382,864 & $2,352,496$ & 449,045 & 548,136 & $2,250,724$ \\
\hline 5 & 102,655 & 118,996 & 452,049 & $-1,036,568$ & 822,959 & 921,726 & 505,181 & 585,598 & $2,224,603$ \\
\hline 6 & 403,978 & 479,053 & $1,515,914$ & $-654,326$ & $1,560,449$ & $-3,165,012$ & 18,607 & 22,065 & 69,823 \\
\hline 7 & 334,753 & 406,352 & $1,277,220$ & $-664,779$ & $1,836,290$ & $-2,667,897$ & 134,283 & 163,004 & 512,344 \\
\hline 8 & $-26,723$ & $-23,581$ & $-125,662$ & $-1,375,499$ & $-1,775,724$ & $1,296,064$ & $-115,093$ & $-101,560$ & $-541,203$ \\
\hline 9 & 516,900 & 632,059 & $1,863,717$ & $-882,187$ & $1,558,019$ & $-5,147,821$ & $-316,479$ & $-386,986$ & $-1,141,085$ \\
\hline 10 & $1,073,745$ & $1,557,978$ & $3,437,222$ & $-549,085$ & $5,053,296$ & $-7,744,799$ & 586,759 & 851,373 & $1,878,305$ \\
\hline 11 & $1,585,759$ & $2,465,049$ & $4,818,204$ & $-556,817$ & $6,622,092$ & $-9,335,847$ & 642,055 & 998,070 & $1,950,834$ \\
\hline 12 & $1,809,297$ & $3,000,788$ & $5,783,056$ & $-1,045,030$ & $7,124,423$ & $-9,494,810$ & 696,743 & $1,155,575$ & $2,227,000$ \\
\hline 13 & 284,780 & 387,518 & $1,528,533$ & $-2,568,662$ & 230,651 & 121,389 & 517,044 & 703,573 & $2,775,189$ \\
\hline 14 & $-705,470$ & $-598,457$ & $-3,967,914$ & $-1,790,812$ & $-2,315,529$ & $6,064,956$ & 536,120 & 454,796 & $3,015,406$ \\
\hline 15 & $-1,415,640$ & $-940,673$ & $-6,327,343$ & $-167,713$ & $-2,273,449$ & 4,907,009 & 166,254 & 110,473 & 743,088 \\
\hline 16 & $-2,460,934$ & $-1,658,418$ & $-10,757,243$ & $-15,760$ & $-1,902,457$ & $4,157,757$ & $-69,841$ & $-47,066$ & $-305,291$ \\
\hline 17 & 343,832 & 323,559 & $1,189,648$ & 770,331 & 616,957 & $-1,081,161$ & 599,142 & 563,815 & $2,073,010$ \\
\hline 18 & 456,945 & 410,383 & $1,441,352$ & 876,919 & 234,940 & $-3,912,621$ & 522,924 & 469,638 & $1,649,469$ \\
\hline 19 & 195,870 & 183,744 & 646,104 & 614,774 & 441,695 & $-3,129,223$ & 452,179 & 424,185 & $1,491,575$ \\
\hline 20 & $-1,060,561$ & $-667,444$ & $-4,068,957$ & 911,389 & $-2,108,161$ & $3,563,860$ & 361,716 & 227,639 & $1,387,763$ \\
\hline 21 & $-1,820,907$ & $-1,048,643$ & $-7,039,433$ & 985,917 & $-2,310,492$ & $4,139,580$ & 230,354 & 132,659 & 890,525 \\
\hline 22 & $-1,159,088$ & $-671,007$ & $-3,655,996$ & $1,981,108$ & $-1,903,410$ & 128,136 & $-433,614$ & $-251,023$ & $-1,367,705$ \\
\hline 23 & $-1,906,848$ & $-1,489,700$ & $-6,588,402$ & $1,023,159$ & $-532,794$ & 516,873 & $-664,027$ & $-518,763$ & $-2,294,299$ \\
\hline 24 & $-3,080,314$ & $-2,449,194$ & $-13,184,911$ & $-14,314$ & $-1,003,830$ & $3,017,631$ & $-370,373$ & $-294,488$ & $-1,585,337$ \\
\hline 25 & $-3,220,510$ & $-2,775,360$ & $-13,072,520$ & 72,186 & $-490,814$ & $1,763,029$ & $-610,288$ & $-525,932$ & $-2,477,250$ \\
\hline 26 & $-2,078,893$ & $-1,399,420$ & $-7,162,736$ & $1,243,166$ & $-1,277,444$ & $1,139,029$ & $-527,257$ & $-354,927$ & $-1,816,642$ \\
\hline 27 & $-1,403,841$ & $-977,492$ & $-4,506,479$ & $1,802,795$ & $-914,024$ & 275,932 & $-376,414$ & $-262,096$ & $-1,208,329$ \\
\hline 28 & $-590,274$ & $-413,041$ & $-1,739,582$ & $2,343,419$ & $-681,141$ & $-1,362,883$ & $-436,640$ & $-305,537$ & $-1,286,812$ \\
\hline 29 & $-2,367,987$ & $-1,821,298$ & $-10,833,474$ & $-423,065$ & $-1,531,273$ & $3,538,713$ & $-316,972$ & $-243,794$ & $-1,450,140$ \\
\hline 30 & $-1,208,345$ & $-921,959$ & $-3,916,446$ & $1,315,714$ & $-562,507$ & $-714,160$ & $-823,818$ & $-628,567$ & $-2,670,128$ \\
\hline 31 & $-2,070,757$ & $-1,688,758$ & $-7,900,207$ & 395,433 & $-675,292$ & 1,397,749 & $-671,580$ & $-547,692$ & $-2,562,166$ \\
\hline
\end{tabular}


Table C3. Decomposition effects. Year 2014.

\begin{tabular}{|c|c|c|c|c|c|c|c|c|c|}
\hline \multirow[t]{2}{*}{ Day } & \multicolumn{3}{|c|}{ Price effect } & \multicolumn{3}{|c|}{ Structure effect } & \multicolumn{3}{|c|}{ Scale effect } \\
\hline & $\begin{array}{l}\text { Conventional } \\
\text { hydraulic }\end{array}$ & $\begin{array}{l}\text { Combined } \\
\text { cycle }\end{array}$ & $\begin{array}{l}\text { Renewable } \\
\text { energies }\end{array}$ & $\begin{array}{c}\text { Conventiona } \\
1 \text { hydraulic }\end{array}$ & $\begin{array}{l}\text { Combined } \\
\text { cycle }\end{array}$ & $\begin{array}{l}\text { Renewable } \\
\text { energies }\end{array}$ & $\begin{array}{l}\text { Conventional } \\
\text { hydraulic }\end{array}$ & $\begin{array}{l}\text { Combined } \\
\text { cycle }\end{array}$ & $\begin{array}{c}\text { Renewable } \\
\text { energies }\end{array}$ \\
\hline 1 & $-1,112,740$ & $-475,616$ & $-3,606,095$ & $-41,225$ & $-1,107,390$ & $5,055,385$ & 554,346 & 236,943 & $1,796,489$ \\
\hline 2 & $-800,409$ & $-350,595$ & $-2,437,775$ & 117,152 & $-952,717$ & $3,086,267$ & 600,258 & 262,925 & $1,828,181$ \\
\hline 3 & 523,531 & 307,468 & $1,346,232$ & 675,078 & 1,318,388 & $-1,748,500$ & 679,164 & 398,870 & $1,746,432$ \\
\hline 4 & $1,172,592$ & 790,524 & $2,453,197$ & $1,678,234$ & $3,558,180$ & $-6,245,717$ & 535,372 & 360,931 & $1,120,059$ \\
\hline 5 & 622,099 & 329,004 & $1,503,641$ & $1,437,999$ & 844,194 & $-2,146,447$ & 677,691 & 358,404 & $1,638,010$ \\
\hline 6 & $-926,148$ & $-414,891$ & $-3,219,856$ & $-888,180$ & $-1,202,654$ & 4,635,302 & $-70,882$ & $-31,753$ & $-246,428$ \\
\hline 7 & $-2,011,839$ & $-1,011,484$ & $-6,853,504$ & $-780,475$ & $-599,904$ & $3,617,949$ & $-224,300$ & $-112,770$ & $-764,097$ \\
\hline 8 & $-801,293$ & $-377,662$ & $-2,555,353$ & $-523,795$ & $-815,377$ & $2,527,833$ & $-418,550$ & $-197,269$ & $-1,334,769$ \\
\hline 9 & $-972,575$ & $-484,210$ & $-3,133,264$ & $-447,444$ & $-520,055$ & $3,423,020$ & 571,561 & 284,559 & $1,841,350$ \\
\hline 10 & 62,833 & 39,232 & 166,962 & 78,168 & $1,451,414$ & $-2,033,145$ & 545,481 & 340,592 & $1,449,481$ \\
\hline 11 & 432,268 & 290,380 & $1,038,365$ & 522,466 & $2,549,055$ & $-4,263,886$ & 567,422 & 381,171 & $1,363,022$ \\
\hline 12 & 15,517 & 7,983 & 44,675 & $-262,479$ & $-244,172$ & $-162,379$ & 570,084 & 293,282 & $1,641,319$ \\
\hline 13 & $-688,886$ & $-347,720$ & $-2,356,371$ & $-1,340,118$ & $-876,863$ & $2,325,756$ & $-70,443$ & $-35,557$ & $-240,955$ \\
\hline 14 & $-483,216$ & $-274,948$ & $-1,444,037$ & $-644,547$ & 174,034 & $-115,418$ & $-485,433$ & $-276,209$ & $-1,450,664$ \\
\hline 15 & 424,260 & 275,613 & $1,113,266$ & 402,438 & $2,103,968$ & $-1,693,331$ & 613,174 & 398,336 & $1,608,976$ \\
\hline 16 & $-264,577$ & $-135,562$ & $-870,668$ & $-1,106,946$ & $-695,250$ & $2,174,217$ & 659,602 & 337,962 & $2,170,608$ \\
\hline 17 & $-360,914$ & $-184,422$ & $-1,062,337$ & $-370,703$ & $-338,679$ & 306,390 & 590,644 & 301,811 & $1,738,536$ \\
\hline 18 & 419,835 & 218,436 & $1,005,224$ & $1,089,349$ & 528,755 & $-3,140,520$ & 563,817 & 293,348 & $1,349,963$ \\
\hline 19 & 971,826 & 476,012 & $1,985,723$ & $2,435,346$ & 708,477 & $-5,505,051$ & 418,292 & 204,884 & 854,692 \\
\hline 20 & $-208,769$ & $-96,458$ & $-519,493$ & 726,713 & $-401,818$ & $-2,350,619$ & $-489,006$ & $-225,936$ & $-1,216,827$ \\
\hline 21 & $-545,946$ & $-272,368$ & $-1,400,136$ & 314,054 & $-126,840$ & $-2,293,741$ & $-727,009$ & $-362,698$ & $-1,864,489$ \\
\hline 22 & 330,033 & 182,859 & 778,724 & 879,880 & 909,118 & $-3,847,770$ & $-70,567$ & $-39,098$ & $-166,505$ \\
\hline 23 & 498,996 & 263,957 & $1,086,685$ & $1,177,840$ & 703,734 & $-5,524,460$ & $-223,092$ & $-118,010$ & $-485,836$ \\
\hline 24 & $-437,794$ & $-181,539$ & $-927,180$ & 903,920 & $-843,578$ & $-5,974,842$ & $-1,136,578$ & $-471,302$ & $-2,407,095$ \\
\hline 25 & $-1,115,474$ & $-584,358$ & $-3,022,108$ & $-149,197$ & $-69,173$ & $-1,716,972$ & $-1,263,961$ & $-662,145$ & $-3,424,398$ \\
\hline 26 & $-898,874$ & $-450,383$ & $-2,326,533$ & 526,833 & 8,924 & $-1,433,154$ & $-812,833$ & $-407,272$ & $-2,103,835$ \\
\hline 27 & $-1,763,069$ & $-893,499$ & $-6,400,206$ & $-1,273,393$ & $-805,336$ & $3,885,744$ & $-472,822$ & $-239,620$ & $-1,716,414$ \\
\hline 28 & $-2,994,277$ & $-1,537,284$ & $-12,416,779$ & $-1,689,787$ & $-949,820$ & $5,398,084$ & $-203,061$ & $-104,253$ & $-842,062$ \\
\hline 29 & $-1,613,645$ & $-723,576$ & $-5,698,681$ & $-1,063,476$ & $-1,241,941$ & $4,267,869$ & 127,853 & 57,331 & 451,521 \\
\hline 30 & $-1,189,333$ & $-571,015$ & $-3,549,121$ & $-235,814$ & $-595,688$ & $1,071,604$ & $-55,936$ & $-26,855$ & $-166,919$ \\
\hline 31 & $-672,894$ & $-305,892$ & $-1,930,787$ & $-259,670$ & $-867,971$ & $-326,379$ & $-683,186$ & $-310,570$ & $-1,960,318$ \\
\hline
\end{tabular}

